\title{
Insulin and the insulin receptor collaborate to promote human gastric cancer
}

\author{
Marina Saisana $^{1} \cdot$ S. Michael Griffin ${ }^{1,2} \cdot$ Felicity E. B. May ${ }^{1,3,4}$ (D)
}

Received: 2 June 2021 / Accepted: 12 August 2021 / Published online: 23 September 2021

(C) The Author(s) 2021

\begin{abstract}
Background Gastric adenocarcinoma is common and consequent mortality high. Presentation and mortality are increased in obese individuals, many of whom have elevated circulating insulin concentrations. High plasma insulin concentrations may promote, and increase mortality from, gastric adenocarcinoma. Tumour promotion activities of insulin and its receptor are untested in gastric cancer cells.

Methods Tumour gene amplification and expression were computed from sequencing and microarray data. Associations with patient survival were assessed. Insulin-dependent signal transduction, growth, apoptosis and anoikis were analysed in metastatic cells from gastric adenocarcinoma patients and in cell lines. Receptor involvement was tested by pharmacological inhibition and genetic knockdown. RNA was analysed by RT-PCR and proteins by western transfer and immunofluorescence. Results INSR expression was higher in tumour than in normal gastric tissue. High tumour expression was associated with worse patient survival. Insulin receptor was detected readily in metastatic gastric adenocarcinoma cells and cell lines. Isoforms B and A were expressed. Pharmacological inhibition prevented cell growth and division, and induced caspasedependent cell death. Rare tumour INS expression indicated tumours would be responsive to pancreatic or therapeutic insulins. Insulin stimulated gastric adenocarcinoma cell PI3-kinase/Akt signal transduction, proliferation, and survival. Insulin receptor knockdown inhibited proliferation and induced programmed cell death. Type I IGF receptor knockdown did not induce cell death.

Conclusions The insulin and IGF signal transduction pathway is dominant in gastric adenocarcinoma. Gastric adenocarcinoma cell survival depends upon insulin receptor. That insulin has direct cancer-promoting effects on tumour cells has implications for clinical management of obese and diabetic cancer patients.
\end{abstract}

Keywords Insulin · Insulin receptor · Gastric cancer · Obesity $\cdot$ Insulin-like growth factor

Felicity E. B. May

F.E.B.May@ncl.ac.uk

1 Newcastle University Centre for Cancer, Translational and Clinical Research Institute, Faculty of Medical Sciences, University of Newcastle-upon-Tyne, Framlington Place, Newcastle-upon-Tyne NE2 4HH, UK

2 Department of Surgery, Newcastle-upon-Tyne Hospitals NHS Foundation Trust, Newcastle-upon-Tyne NE1 4LP, UK

3 Department of Pathology, Faculty of Medical Sciences, University of Newcastle-upon-Tyne, Framlington Place, Newcastle-upon-Tyne NE2 4HH, UK

4 Department of Oncology, Newcastle-upon-Tyne Hospitals NHS Foundation Trust, Newcastle-upon-Tyne NE1 4LP, UK

\section{Introduction}

Gastric cancer is the second leading cause of cancer-related death worldwide; 783,000 patients die annually [1]. Many patients present with incurable, late-stage disease and systemic treatment options are limited [2]. Genomic studies identified gene amplification of ERBB2, EGFR, FGFR2, $M E T$ and $I G F 1 R$, that encode targetable tyrosine kinase receptors [3] and activating mutations in KRAS, BRAF [4] and PI3KCA. [3] Gastric adenocarcinoma patients with advanced disease and amplified $E R B B 2$ are eligible for trastuzumab therapy [5]. Otherwise, targeted therapies have had relatively little impact. Phase II clinical trials of drugs against FGFR2 and c-Met were promising but phase III trials disappointed [6]. The majority of gastric adenocarcinoma 
patients, around $70 \%$, would be ineligible for these targeted agents [7].

Epidemiological studies indicate that insulin promotes higher rates of gastric cancer presentation and mortality. Obesity is associated positively with gastric cancer incidence and mortality $[8,9]$. Obesity leads to insulin resistance, compensatory hyperinsulinemia, metabolic syndrome and type II diabetes mellitus [10]. High therapeutic insulin doses are required to overcome insulin resistance in type II diabetes. Preceding hyperinsulinemia and high therapeutic insulin concentrations could explain the prevalence of gastric cancer in type II diabetics [11, 12]. There is a positive association between plasma insulin levels and gastric cancer incidence [13]. Treatment of type II diabetes with metformin, which lowers insulin secretion [14], reduces gastric cancer incidence $[15,16]$ Type I diabetics have also increased gastric cancer incidence [17, 18], that reaches 3.3fold after 15 years of insulin therapy [17].

The insulin signal transduction pathway is activated by three ligands, insulin, insulin-like growth factor 1 (IGF-1) and insulin-like growth factor 2 (IGF-2) via interaction with two closely-related tyrosine kinase receptors. $[10,19]$ The insulin and type I IGF receptors signal through common downstream intracellular pathways. The insulin receptor has two isoforms [20]. Isoform B is present across species whereas isoform $\mathrm{A}$, which is expressed in foetal cells, is found uniquely in mammals [21].

Despite epidemiological evidence that high circulating insulin concentrations, secreted by the pancreas in overweight individuals or injected to treat diabetes, promote gastric cancer and increase ensuant mortality, the possibility that insulin has direct tumour-promoting effects upon the malignant cells themselves has not been tested. Objectives were to investigate if insulin promotes directly gastric adenocarcinoma cell proliferation or survival, and to explore the relative importance of the insulin receptor.

\section{Materials and methods}

\section{Isolation of metastatic cells}

Ethical permission was obtained from the Joint Newcastle Health Hospitals and University of Newcastle-upon-Tyne Ethical Committee to obtain metastatic patient samples for ex vivo analyses. All patients gave informed consent. Ascitic fluid rich in disseminated tumour cells, was drained from the peritoneal cavities of patients with advanced gastric adenocarcinoma (Table 1). The cell suspension was diluted 1:1 with Dulbecco's modified Eagle's medium (DMEM), 20\% untreated foetal calf serum (FCS) and $1 \%$ penicillin/streptomycin (Sigma) and maintained at $37^{\circ} \mathrm{C}$.

\section{Cell culture}

Gastric adenocarcinoma cell lines were purchased from ATCC. NCI-N87, MKN74, NUGC3, AGS were cultured as adherent monolayers, SNU-1, SNU-5 and SNU-16 in suspension and KATO III as a mix of adherent and suspension cells in DMEM with $10 \%$ untreated FCS or $20 \%$ untreated FCS (SNU-5). NCI-N87 have amplified ERBB2, KATO III and SNU-16 have amplified FGFR2 and SNU-5 have amplified MET. SNU-1, MKN74, NUGC3 and AGS are triple-negative for amplification of these three targetable tyrosine kinase receptor oncogenes [7]. SNU-1 have activated KRAS-G12D, MKN74 have impaired BRAF-G466V and AGS have activated KRAS-G12D and PIK3CA-E453K/ E545A [7]. Cells were tested to confirm absence of mycoplasma and $100 \%$ authenticity confirmed by STR analysis.

\section{Stimulation of phosphorylation}

Cells were placed in $22 \mathrm{~mm}$-diameter wells at 100,000-150,000 cells/well, incubated for $24-48 \mathrm{~h}$, washed with phosphate buffered serum $\mathrm{pH} 7.2$ (PBS) and withdrawn

Table 1 Clinicopathological features of patients from whom metastatic cells were isolated

\begin{tabular}{|c|c|c|c|c|c|c|c|}
\hline Patient ID & Sex & Age (years) & Diagnosis & Stage at diagnosis & Systemic treatment & HER2 status primary & $\begin{array}{l}\text { HER2 status } \\
\text { disseminated } \\
\text { cells }\end{array}$ \\
\hline $\mathrm{GC} 1$ & Male & $\sim 65$ & Gastric adenocarcinoma & T4N2M1 & $\begin{array}{l}\text { Symptom control with } \\
\text { palliative drain }\end{array}$ & N.D & Negative \\
\hline JW1 & Male & 75 & $\begin{array}{l}\text { Gastric adenocarci- } \\
\text { noma, poorly differ- } \\
\text { entiated }\end{array}$ & T4N1M1 & $\begin{array}{l}\text { Palliative radiotherapy, } \\
30 \text { Gy in } 10 \text { fractions }\end{array}$ & N.D & Negative \\
\hline $\mathrm{HC} 1$ & Female & 68 & $\begin{array}{l}\text { Gastric adenocarci- } \\
\text { noma, diffuse type, } \\
\text { linus plastica }\end{array}$ & T3N1M0 & $\begin{array}{l}\text { Three cycles of peri- } \\
\text { operative ECX }\end{array}$ & N.D & Negative \\
\hline $\mathrm{NC1}$ & Female & 52 & $\begin{array}{l}\text { Gastric adenocarci- } \\
\text { noma, of the cardia }\end{array}$ & T4N2M1 & $\begin{array}{l}\text { Symptom control with } \\
\text { palliative drain }\end{array}$ & Negative & Negative \\
\hline
\end{tabular}


from stimulation by growth and survival factors that are present in serum by culture in withdrawal medium for one (SNU-1) or two days. Withdrawal medium comprised phenol red-free DMEM and 10\% calf serum that had been incubated with dextran-coated charcoal at $55{ }^{\circ} \mathrm{C}$ to remove steroids and growth and survival factors [22, 23]. Cells were washed and incubated with serum-free, phenol red-free DMEM and $0.1 \%$ bovine serum albumin (BSA; Sigma-Aldrich) at $37^{\circ} \mathrm{C}$ for $2 \mathrm{~h}$ followed by the same serum-free medium plus insulin, IGF-1 or IGF-2 for $15 \mathrm{~min}-1 \mathrm{~h}$. Cells were incubated with BMS-754807, for 30 min before addition of ligand.

\section{Western transfer}

Cells were lysed in radioimmunoprecipitate (RIPA) buffer and analysed by western transfer as described [24] with antibodies against: insulin receptor (\#3025), type I IGF receptor (\#3027), $\beta$-tubulin (\#5346), phosphorylated Tyr 1150/1151 insulin and Tyr 1135/1136 type I IGF receptors (\#3024), Akt (\#9272), phosphorylated Ser 473 Akt (\#4060), ERK1 and ERK2 (\#9102), phosphorylated Thr 202/204 ERK1 and Thr 185/187 ERK2 (\#4370), cleaved Asp 214 poly-(ADP-ribose) polymerase-1 (PARP-1) (\#9541) (Cell Signaling Technologies), or GAPDH-HRP (sc-25778) (Santa Cruz Biotechnology). Protein bands were quantified by densitometry and adjusted for GAPDH, $\beta$-tubulin or the corresponding total protein [24].

\section{Apoptosis}

Between 100,000 and 150,000 cells were added to $22 \mathrm{~mm}$ diameter wells and incubated for $24 \mathrm{~h}$. Cells were withdrawn from growth and survival factors in serum by culture in withdrawal medium for one (SNU-1) or two days [22, 24]. Cells were incubated with 0-200 $\mathrm{ngml}^{-1}$ of insulin, IGF-1 or IGF-2 in withdrawal medium for 15 min before treatment with $0.5-1 \mu \mathrm{M}$ staurosporine (Sigma-Aldrich, Dorset, United Kingdom) for 4-5 h. Alternatively, cells were cultured in DMEM with untreated FCS and different concentrations of BMS-754807.

For anoikis, culture vessels were coated with poly(hydroxyethyl methacrylic) (poly-HEMA; SIGMA) which inhibits matrix deposition and hence cell attachment [7, 24]. Cells were added to $35 \mathrm{~mm}$-diameter poly-HEMAcoated wells at 400,000 cells/well and cultured in serumfree medium in the absence or presence of ligand or BMS754807 for $24 \mathrm{~h}$ [24].

\section{siRNA knockdown}

Double-stranded, short-interfering RNA sequences against insulin receptor and type I IGF receptor, and scrambled sequences were purchased from Sigma-Aldrich.
Oligonucleotides and lipofectamine (Invitrogen, Paisley, United Kingdom) were pre-incubated for $30 \mathrm{~min}$ at room temperature and added to cells in suspension in the presence of untreated FCS. Cells were plated at 50,000 cells per 1.9 $\mathrm{cm}^{2}$ and incubated for $\geq 24 \mathrm{~h}$ in untreated FCS-containing medium.

\section{Immunofluorescence}

Cells were fixed in methanol, $70 \%$ ethanol or $4 \%$ paraformaldehyde and incubated with Alexa Fluor-conjugated antibodies against cleaved Asp 175 caspase-3 (\#9603), cleaved Asp 214 PARP-1 (\#6894), or unconjugated-antibodies against BrdU (\#5292) or phosphorylated Ser 10 histone H3 [25] (\#9701) (Cell Signaling Technologies), followed by Alexa Fluor-conjugated secondary antibodies (\#A-11034, \#A-11001) (Invitrogen). For BrdU incorporation, cells were treated with $0.03 \mathrm{mg} / \mathrm{ml} \mathrm{BrdU}$ for $2 \mathrm{~h}$ before and $1.5 \mathrm{M} \mathrm{HCl}$ for $30 \mathrm{~min}$ after fixation. Cells were mounted in Vectashield with DAPI (Vector Laboratories).

\section{Proliferation}

Cells were added to $16 \mathrm{~mm}$-diameter wells at 5000-10,000 cells/well, cultured in withdrawal medium for $24 \mathrm{~h}$ and then in withdrawal medium minus and plus $50 \mathrm{ng} / \mathrm{ml}$ insulin, IGF-1 or IGF-2 for $0,3,6$, or 9 days. Alternatively, cells were cultured in untreated FCS-containing medium and different BMS-754807 concentrations. Cells were lysed in $0.15 \mathrm{M} \mathrm{NaCl}, 15 \mathrm{mM}$ sodium citrate, $\mathrm{pH} 7.0$, and $0.02 \%$ SDS at $37{ }^{\circ} \mathrm{C}$ for $30 \mathrm{~min}$. DNA was sheared and measured with PicoGreen dsDNA Quantitation Reagent (Invitrogen) $[7,23]$.

\section{Reverse transcription polymerase chain reaction (RT-PCR)}

RNA was extracted with Direct-zol ${ }^{\mathrm{TM}}$ RNA MiniPrep Kit (Zymo Research, California). cDNA was synthesised from $1 \mu \mathrm{g}$ RNA with Moloney Murine Leukaemia Virus Reverse Transcriptase (USB) in a $20 \mu \mathrm{l}$ reaction and $0.1 \mu \mathrm{l}$ cDNA amplified with Red Hot DNA polymerase (Thermo-scientific) in $10 \mu 1$ [26, 27]. Primers designed with PrimerBLAST were synthesised by SIGMA-Aldrich. Amplicons were analysed on 3\% agarose gels, stained with GelRed (Cambridge Bioscience, Cambridge, UK).

\section{Patient cohort analyses and statistics}

For survival analyses, tumour gene expression was measured by Affymtrix array hybridisation in 882 patients [28] and by RNA-Seq in 392 patients [29]. Copy number variation $(\mathrm{CNV})$ and gene expression data deduced by genomic and 
a

\begin{tabular}{|l|r|r|}
\hline Ligand & \multicolumn{1}{|c|}{$\begin{array}{c}\text { Insulin } \\
\text { receptor }\end{array}$} & $\begin{array}{c}\text { Type I IGF } \\
\text { receptor }\end{array}$ \\
\hline insulin & $0.5 \mathrm{nM}$ & $100 \mathrm{nM}$ \\
\hline IGF-1 & $100 \mathrm{nM}$ & $0.2 \mathrm{nM}$ \\
\hline IGF-2 & $10 \mathrm{nM}$ & $0.5 \mathrm{nM}$ \\
\hline
\end{tabular}

INSR $3 \%$ IIIII |

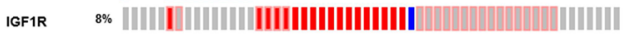

INSR IGF1R

Genetic Alteration | Ampilication || Deep Deletion || mRNA Upregulation || No alterations

b

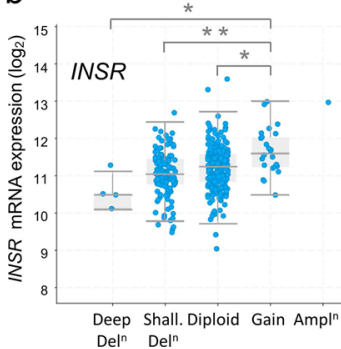

$\begin{array}{cc}\text { Deep } & \text { Shall. } \\ \text { Del }^{n} & \text { Del }^{n}\end{array}$

$\begin{array}{lllll}\text { Number } & 4 & 130 & 210 & 24\end{array}$
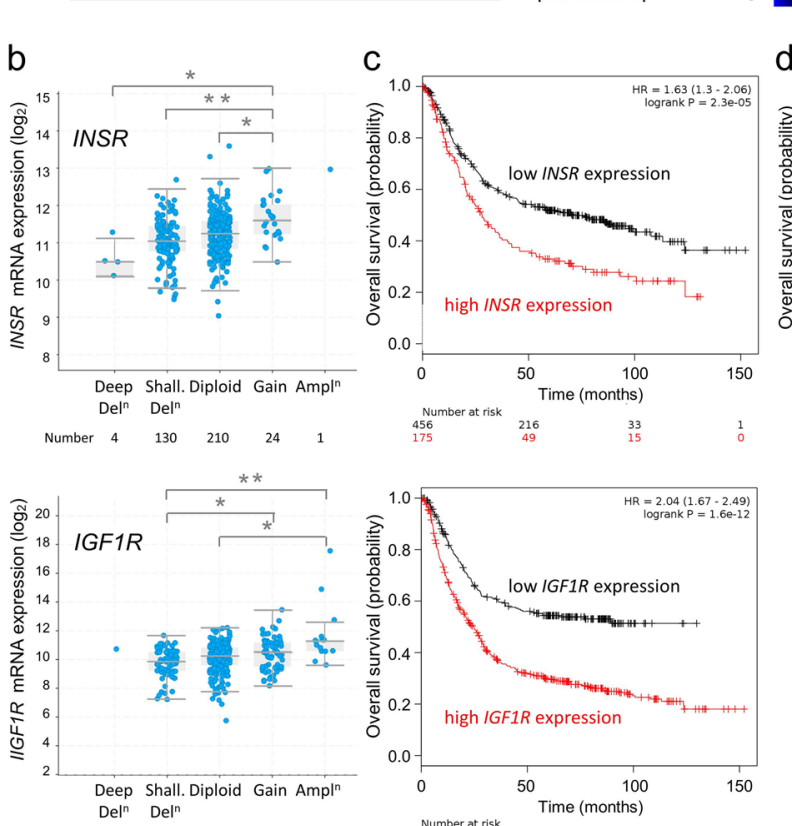

d
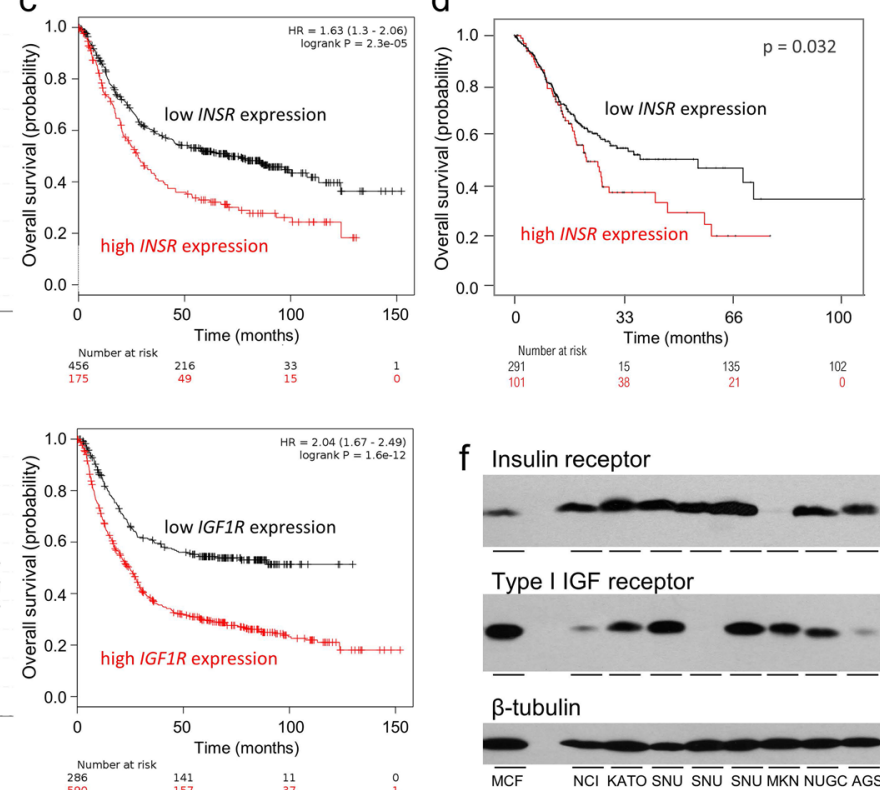

f Insulin receptor

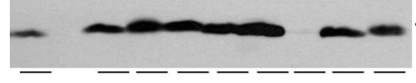

Type I IGF receptor

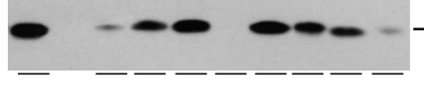

$\beta$-tubulin

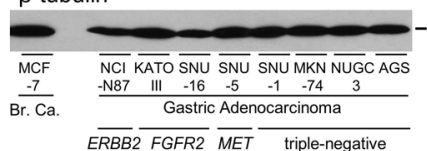

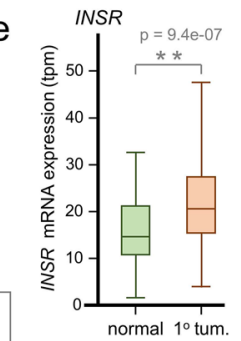
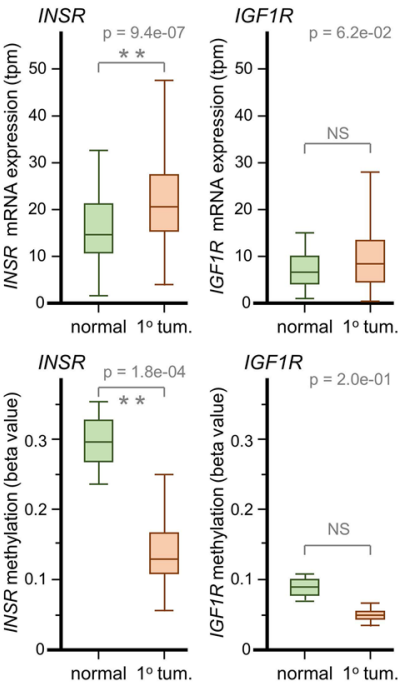

Insulin receptor

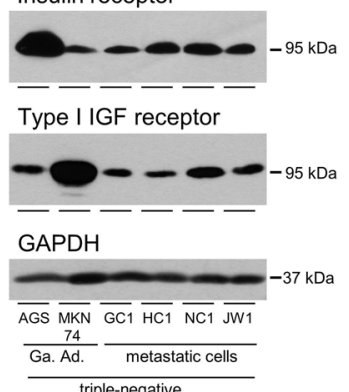

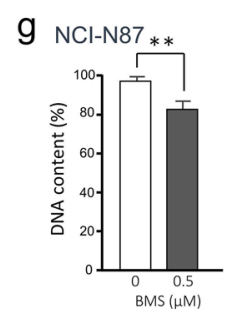
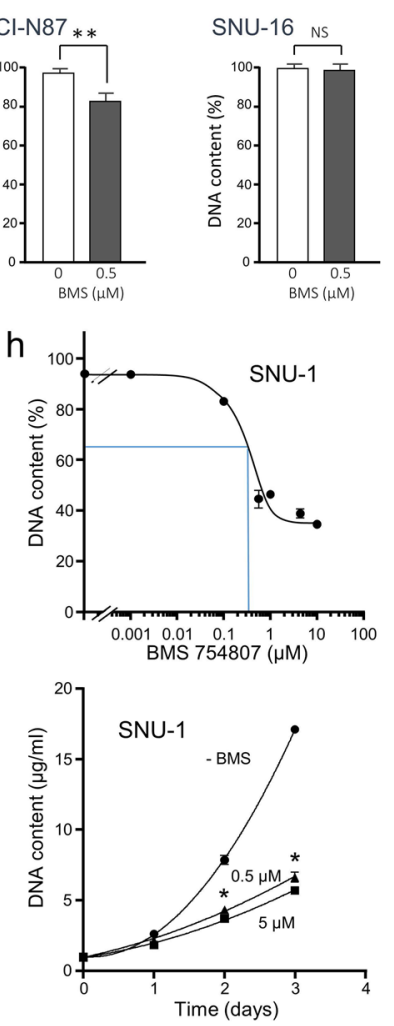
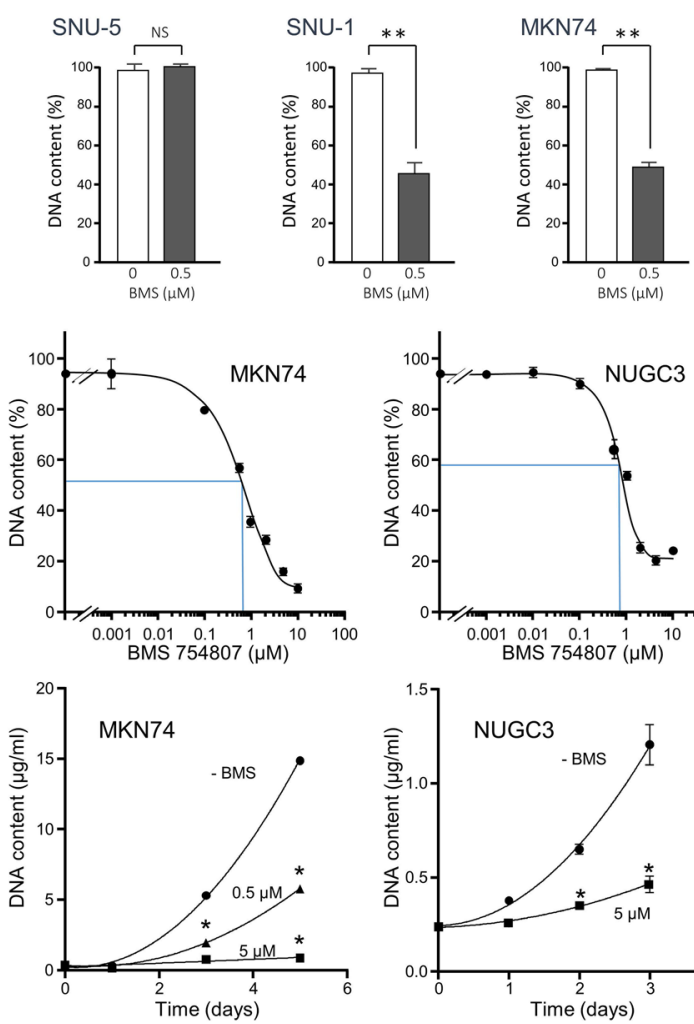
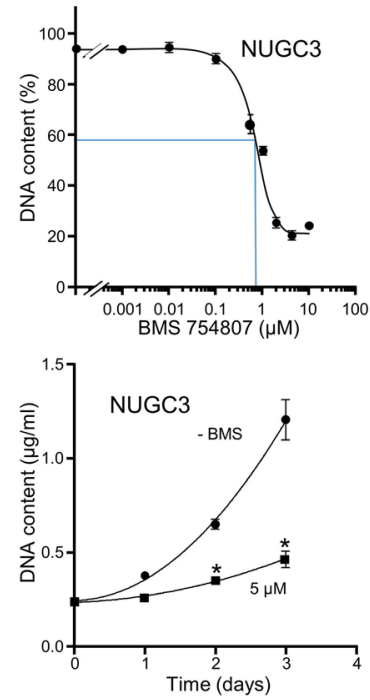
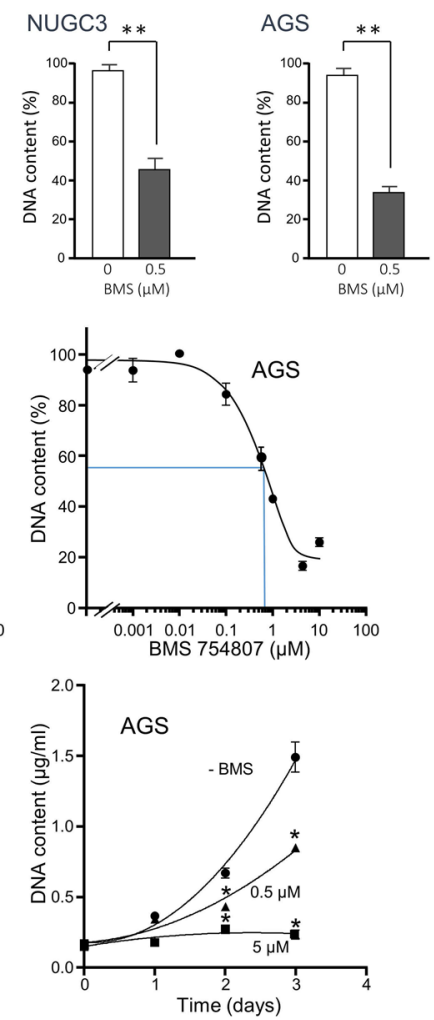
4Fig. 1 Expression of genes that encode, and inhibition of, the insulin and type I IGF receptors in gastric adenocarcinoma. a The affinities of insulin, IGF-1 and IGF-2 for the insulin and type I IGF receptors are shown (adapted from [10]). Original references are included in the electronic supplementary material (Online Resource 1). Copy number and relative high expression of $>2$ SD from the mean for diploid tumours of the genes that encode the insulin receptor (INSR) and type I IGF receptor $(I G F 1 R)$ were analysed for 478 gastric adenocarcinomas $[49,50]$. b $\log _{2}$ transformed mRNA relative abundance deduced from absolute transcript abundance by RNA-Seq expectation maximization (RSEM) [51] is shown against the putative copynumber alterations deduced from genomic sequencing data analysed with GISTIC 2.0. Horizontal bars represent the median values, boxes the range of the second and third quartiles of the data and whiskers the range of all data. Expression of INSR and IGF1R, is associated with CNV (Kruskal Wallis; $p<0.0001$ ); statistically significant differences between groups are indicated (Dunn-Boniferroni post hoc; ${ }^{*} p<0.05$ (INSR); *p<0.005 (IGF1R); **p<0.0001 (either)). c Kaplan and Meier curves illustrate correlations analysed by the $\log$ rank test between INSR and IGFIR expression, and overall survival for 876 gastric cancer patients [28]. d Kaplan and Meier curves illustrate correlation analysed by the log rank test between INSR expression, and overall survival for 392 gastric cancer patients [29]. e INSR and $I G F I R$ expression calculated as transcripts per million (tpm) in normal $(n=34)$ and primary gastric tumour ( $1^{\circ}$ tum.; $\left.n=415\right)$ tissue (Student's $t$-test; $p<0.0001$ and $p=0.06$, respectively) and methylation status upstream of INSR and IGFIR transcription start sites (Student's $t$-test; $p<0.0002$ and $p=0.195$, respectively). f MCF-7 breast cancer cells (Br. Ca.), NCI-N87, KATO III, SNU-16, SNU-5, SNU-1, MKN74, NUGC3 and AGS gastric adenocarcinoma cells (Ga. Ad.) and metastatic cells isolated from gastric adenocarcinoma patients, $\mathrm{GC} 1, \mathrm{HC} 1, \mathrm{NC} 1$ and JW1, were lysed and insulin receptor, type I IGF receptor, $\beta$-tubulin or GAPDH were analysed by western transfer. ERBB2, FGFR2 and MET are amplified and overexpressed in NCI-N87, KATO III and SNU-16, and SNU-5, respectively. SNU-1, MKN74, NUGC3 and AGS and the metastatic patient cells are triplenegative for amplification or overexpression of these oncogenes [7]. g NCI-N87, SNU-16, SNU-5, SNU-1, MKN-74, NUGC3 and AGS were incubated in full, untreated FCS-containing medium without and with $0.5 \mu \mathrm{M}$ BMS-754807 for three days, lysed and their DNA content measured. Asterisks indicate if there was significantly less DNA in the presence of BMS-754807 than in its absence (Student's $t$-test; $p<0.01)$. h SNU-1, MKN-74, NUGC3 and AGS were incubated in untreated FCS-containing medium and different concentrations of BMS-754807 for three days or as indicated and their DNA content measured. The relative $\mathrm{IC}_{50}$ values are indicated by blue lines. Asterisks indicate times at which there was significantly less DNA in the presence of BMS-754807 than in its absence (one-way ANOVA; $p<0.0001)$

RNA sequencing in 478 gastric tumours were obtained from the Cancer Genome Atlas (TCGA) and analysed. Gene expression was analysed by RNA-Seq in 34 normal gastric tissue samples and in 33 tumour types [29], and by microarray analysis in 1065 gastric adenocarcinomas [28].

Associations between copy number and expression were analysed by Kruskal-Wallis one-way ANOVA with Dunn's post hoc comparison between groups and Boniferroni corrections. Associations between gene expression and overall survival were analysed by the log rank test [28]. Differences between groups were tested by student's t-test, or one-way or two-way analysis of variance (ANOVA). Differences between experimental conditions were tested by Dunnett's or Tukey's multiple comparisons tests.

Representative images of experiments are shown. Triplicate or more samples were analysed. Normalized data are expressed as a percentage of the maximum effect. Results are shown as mean \pm S.E.M. Results of statistical analyses are detailed in the legends to the figures. Differences were considered statistically significantly if $p<0.05$.

\section{Results}

\section{Expression of INSR and IGFIR in gastric adenocarcinoma}

Insulin, IGF-1 and IGF-2 interact with and activate the insulin and type I IGF receptors. But insulin has much higher affinity for the insulin receptor (Fig. 1a), IGF-1 has higher affinity for the type I IGF receptor, whereas IGF-2 has more similar affinities for both receptors [10]. The INSR and $I G F 1 R$ genes, which encode the insulin and type I IGF receptors, were expressed in all gastric adenocarcinomas (Fig. 1b); median relative mRNA abundances were around 10 to $12\left(\log _{2}\right)$. Amplification, deletion or relative overexpression of INSR and IGFIR were detected in $3 \%$ and $8 \%$ of gastric adenocarcinomas, respectively (Fig. 1a). Although amplified rarely, INSR expression, and that of $I G F 1 R$, was associated strongly with CNV (Kruskal Wallis; $p<0.0001$ ). (Fig. 1b).

In terms of patient outcome, higher tumour INSR expression, and IGFIR expression, was associated significantly with shorter overall survival (Fig. 1c). The significant association between high INSR expression and poor survival was corroborated in a separate cohort of 392 patients (Fig. 1d) [29]. Expression of INSR, but not IGF1R, was significantly higher in tumour than in normal gastric tissue (Fig. 1e). There was some indication that reduced promoter methylation might contribute to higher tumour INSR expression.

Receptor levels were analysed in gastric adenocarcinoma cell lines and metastatic cells isolated from the peritoneal cavity of advanced gastric cancer patients (Table 1). ERBB2 is amplified and overexpressed in NCI-N87, FGFR2 in KATO III and SNU-16, and MET in SNU-5. SNU-1, MKN74, NUGC3, AGS and the metastatic patient cells are triple-negative for amplification or overexpression of these three oncogenes [7]. Consistent with relatively high tumour INSR expression, insulin receptor was detected readily in seven of eight cell lines, at lower levels in MKN74 and in metastatic cells (Fig. 1f). Type I IGF receptor was detected as reported previously [7]. Notably, insulin receptor levels are visualised easily in three of the four gastric cancer cell lines and in the metastatic cells that represent the majority of gastric cancers that are triple-negative for $E R B B 2$, 

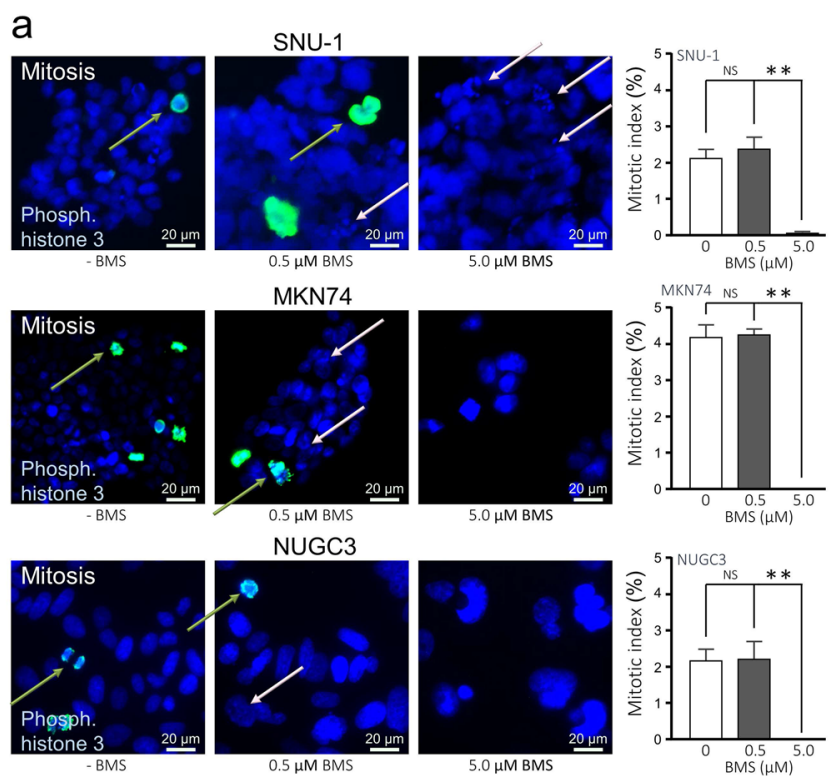

C

metastatic cells

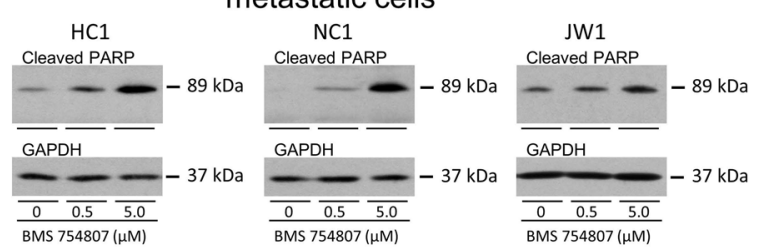

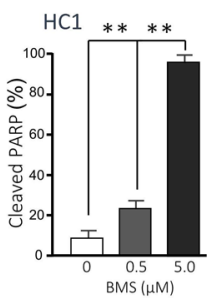

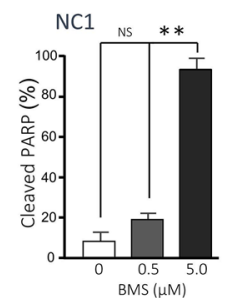

e

SNU-1

Phospho. IGF receptors

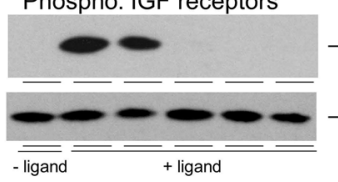

Phospho. Akt
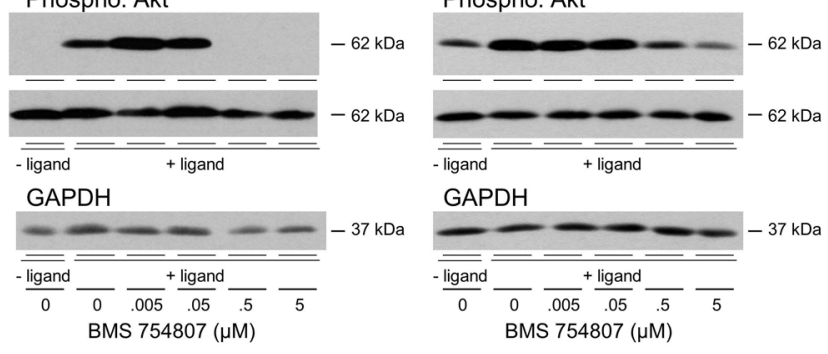

\section{NUGC3}
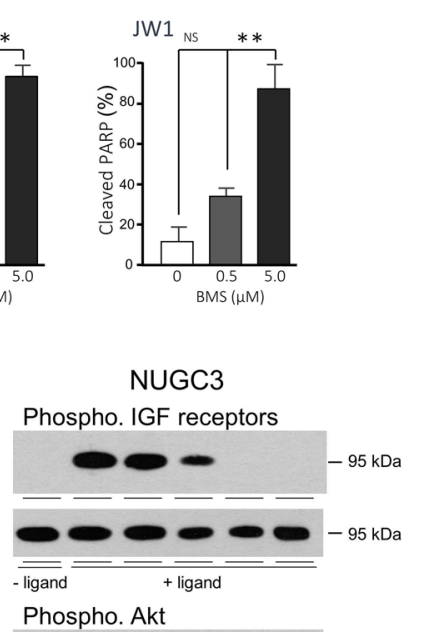

b
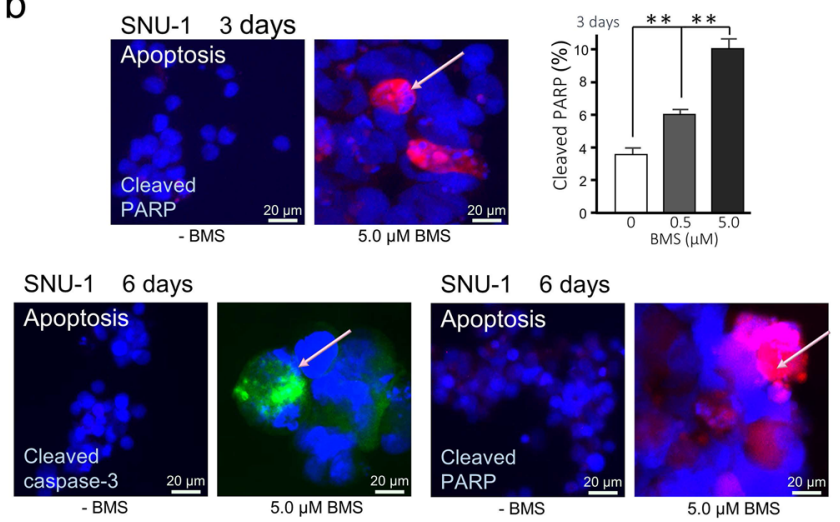

d
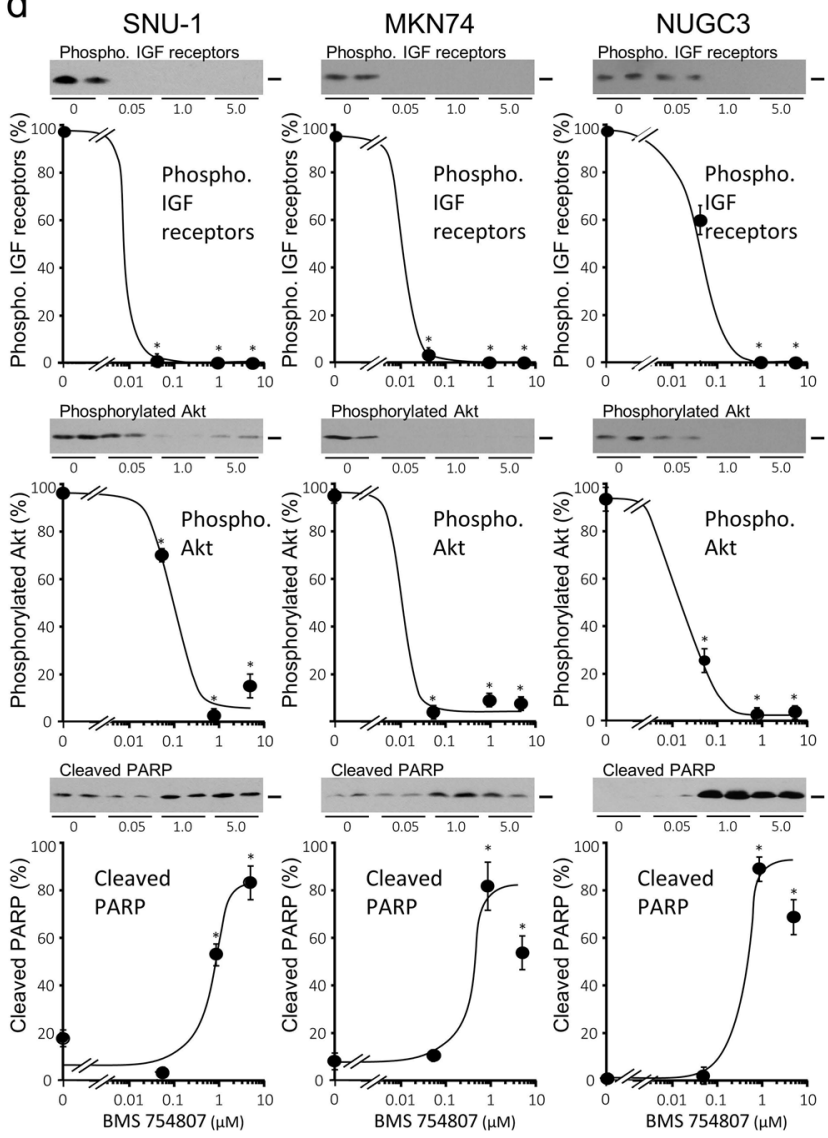

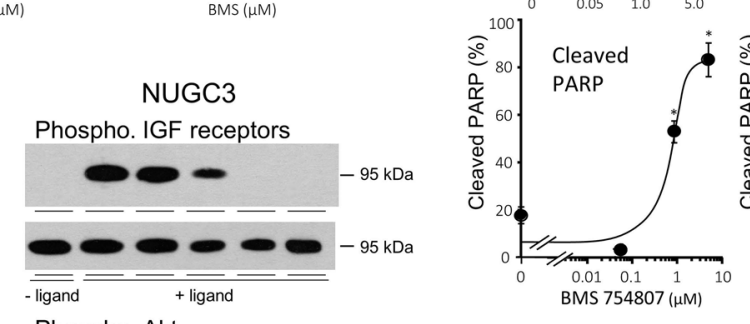


4Fig. 2 Pharmacological inhibition of the insulin and type I receptors induces cell death a SNU-1 were cultured in suspension, whereas MKN74 and NUGC3 were plated onto coverslips, in untreated FCScontaining medium and the indicated concentration of BMS-754807 for three days. Cells were assayed for histone H3 Ser 10 phosphorylation (khaki arrows) by immunofluorescence and counterstained with DAPI. Asterisks indicate that the proportion of cells in the mitotic-phase of the cell cycle is significantly lower after incubation with BMS-754807 (one-way ANOVA; SNU-1, $p=0.0009$; MKN74, $p=0.0046$; NUGC3, $p=0.0023)$. NS indicates data that are not significantly different. Pale pink arrows indicate apoptotic cells. b SNU-1 were incubated in untreated FCS-containing with BMS754807 (BMS) for three or six days. Cleaved caspase-3 or cleaved PARP were analysed by immunofluorescence (pink arrows). Asterisks indicate that the proportion of cells with detectable cleaved PARP is statistically significantly different after incubation with BMS-754807 (one-way ANOVA; $p<0.01$ ). c Metastatic adenocarcinoma cells were isolated from patients and incubated in $20 \%$ untreated FCS-containing medium and different concentrations of BMS-754807 for three days after which cleaved PARP and GAPDH were analysed by western transfer. The protein bands were quantified by densitometry and corrected for GAPDH. Asterisks indicate concentrations of BMS-754807 at which there was statistically significantly more cleaved PARP in its presence than in its absence (oneway ANOVA; $p<0.001)$. d Cells were incubated in full, untreated FCS-containing medium with BMS-754807 for three days and phosphorylated (Phospho.) insulin Tyr 1150/1151 and type I IGF Tyr 1135/1136 receptors (IGF receptors), Akt Ser 473 and cleaved PARP analysed as above, quantified and corrected for corresponding total protein or GAPDH, respectively. Representative images are shown as inserts. Asterisks indicate concentrations of BMS-754807 at which there was statistically significantly less phosphorylated protein, or more cleaved PARP than in its absence (one-way ANOVA; $p<0.001)$. e SNU-1 and NUGC3 were incubated in serum-free medium for two hours and then in serum-free medium and the indicated concentrations of BMS-754807 in the absence or presence of ligand (lig.) for $15 \mathrm{~min}$. Phosphorylated (Phospho.) insulin Tyr 1150/1151 and type I IGF Tyr 1135/1136 receptors (IGF receptors), Akt Ser 473 or GAPDH were measured. Total corresponding protein is shown underneath the phosphorylated protein images

FGFR2 or MET overexpression [7]. Similar levels of insulin receptor were detected in NCI-N87, Kato III and SNU-16, and SNU-5 that have amplification and overexpression of ERBB2, FGFR2, and MET, respectively [7].

\section{Pharmacological inhibition of insulin and type I IGF receptors}

The importance of the insulin and IGF signal transduction pathway was tested with BMS-754807 a specific dual inhibitor of the insulin and type I IGF receptors in gastric adenocarcinoma cells exposed to growth factors present in untreated FCS. There was a reduction in DNA content in NCI-N87, no change in SNU-16 or SNU-5 and a marked reduction in SNU-1, MKN74, NUGC3 and AGS (Fig. 1g). Receptor inhibition was more effective in gastric adenocarcinoma cells that are triple-negative for amplification or overexpression of ERBB2, FGFR2 or MET. Subsequent experiments focused on triple-negative cancer.
Incubation of SNU-1, MKN74, NUGC3 and AGS with different concentrations of BMS-754807 in the presence of untreated FCS demonstrated concentration-dependent reduction in DNA content (Fig. 1h). Relative $\mathrm{IC}_{50}$ values were between 0.35 and $0.7 \mu \mathrm{M}$ BMS-754807. Over time, cell growth was reduced by $0.5 \mu \mathrm{M}$ BMS-754807 in SNU1 , MKN74 and AGS and by $5 \mu \mathrm{M}$ BMS-754807 in all cells (two-way ANOVA; $p<0.0002$ ).

To assess effects of BMS-754807 on cell division, phosphorylation of histone $\mathrm{H} 3 \mathrm{Ser} 10$ which occurs during chromosome condensation in early mitosis [25] was analysed by immunofluorescence. Mitotic SNU-1, MKN74 and NUGC3 were detected after culture in untreated-FCS-containing medium (Fig. 2a), but not after addition of $5 \mu \mathrm{M}$ BMS754807. Pharmacological inhibition of the insulin and type I IGF receptors prevented serum-stimulated gastric adenocarcinoma cell division.

Nuclear fragmentation indicative of apoptosis was visible in some SNU-1, MKN74 and NUGC3 after treatment with $0.5 \mu \mathrm{M}$ BMS-754807 and in some SNU-1 after treatment with $5 \mu \mathrm{M}$ BMS-754807 (Fig. 2a). Induction of programmed cell death was confirmed by detection of cleaved PARP, a product of the executioner caspase- 3 after three days, and of activated, cleaved caspase- 3 and cleaved PARP after 6 days' treatment with BMS-754807 in the presence of FCS (Fig. 2b).

We investigated if pharmacological inhibition induced programmed cell death in metastatic gastric adenocarcinoma cells isolated from patients (Table 1). More cleaved PARP was detected after three days treatment with BMS-754807 in the full complement of growth and survival factors present in untreated FCS (Fig. 2c) (one-way ANOVA; $p<0.001$ ), consistent with the insulin and IGF signal transduction pathway providing a dominant cell survival signal in these metastatic cells.

Concentration-dependent prevention by BMS-754807 of untreated FCS-stimulated IGF receptor phosphorylation and reduced activation of the PI3-kinase/Akt pathway was demonstrated in SNU-1, MKN74 and NUGC3 gastric adenocarcinoma cells (Fig. 2d). PARP cleavage indicative of programmed cell death was induced by 0.5 and $5.0 \mu \mathrm{M}$ BMS-754807 (Fig. 2d). Effective inhibition of ligand-stimulated phosphorylation of IGF receptors and Akt by BMS754807 in serum-free medium was confirmed in SNU-1 and NUGC3 (Fig. 2e).

\section{Expression of INS, IGF1 and IGF2}

Pancreatic or pharmaceutical insulins are unlikely to influence tumour progression if tumours synthesise insulin in biologically significant amounts. Relative mRNA abundance analysis demonstrated that INS, which encodes insulin, is not expressed in the majority, and weakly in a tiny 

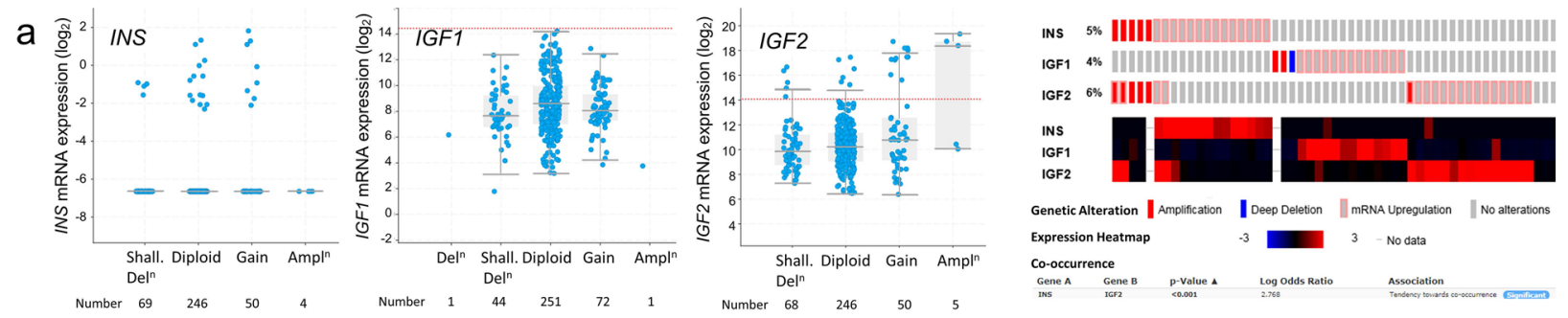

$\mathrm{b}$ है

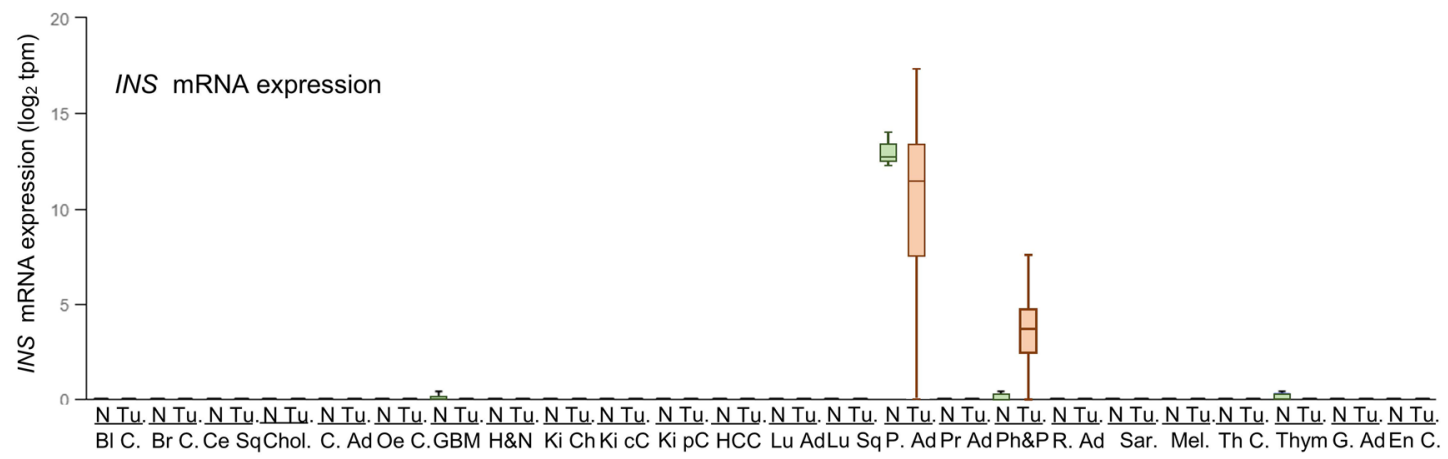

C

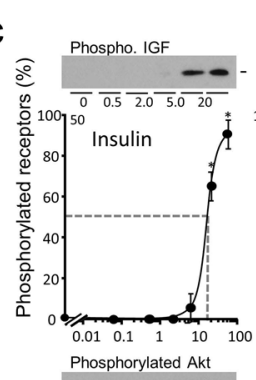

SNU-1
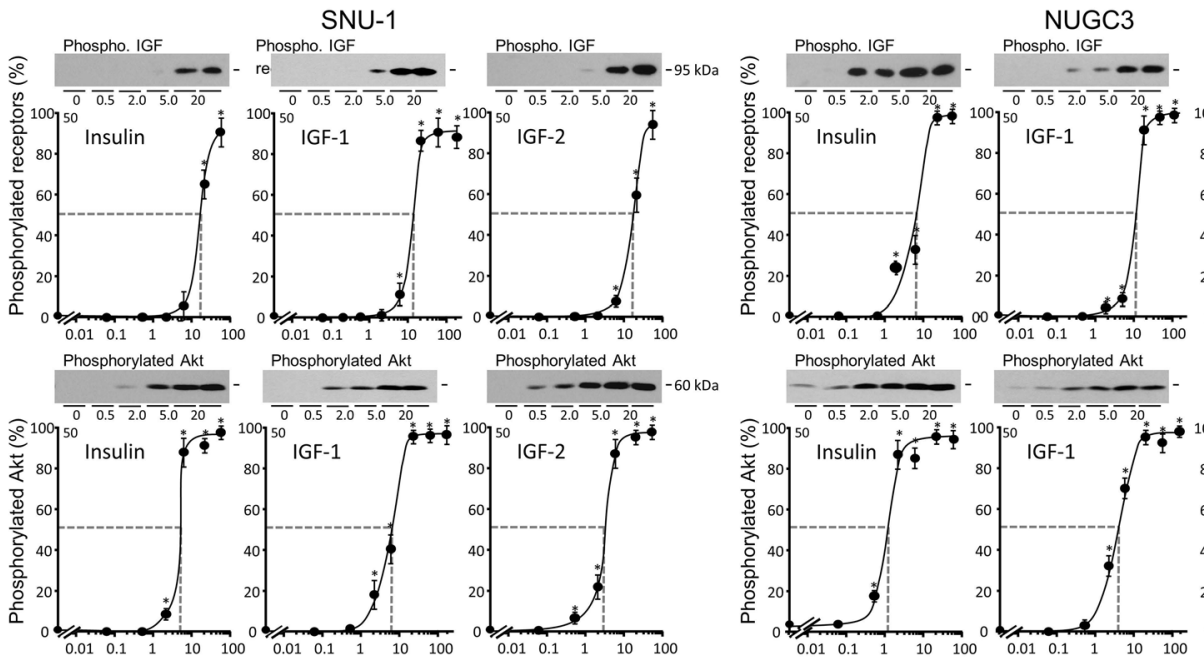

NUGC3
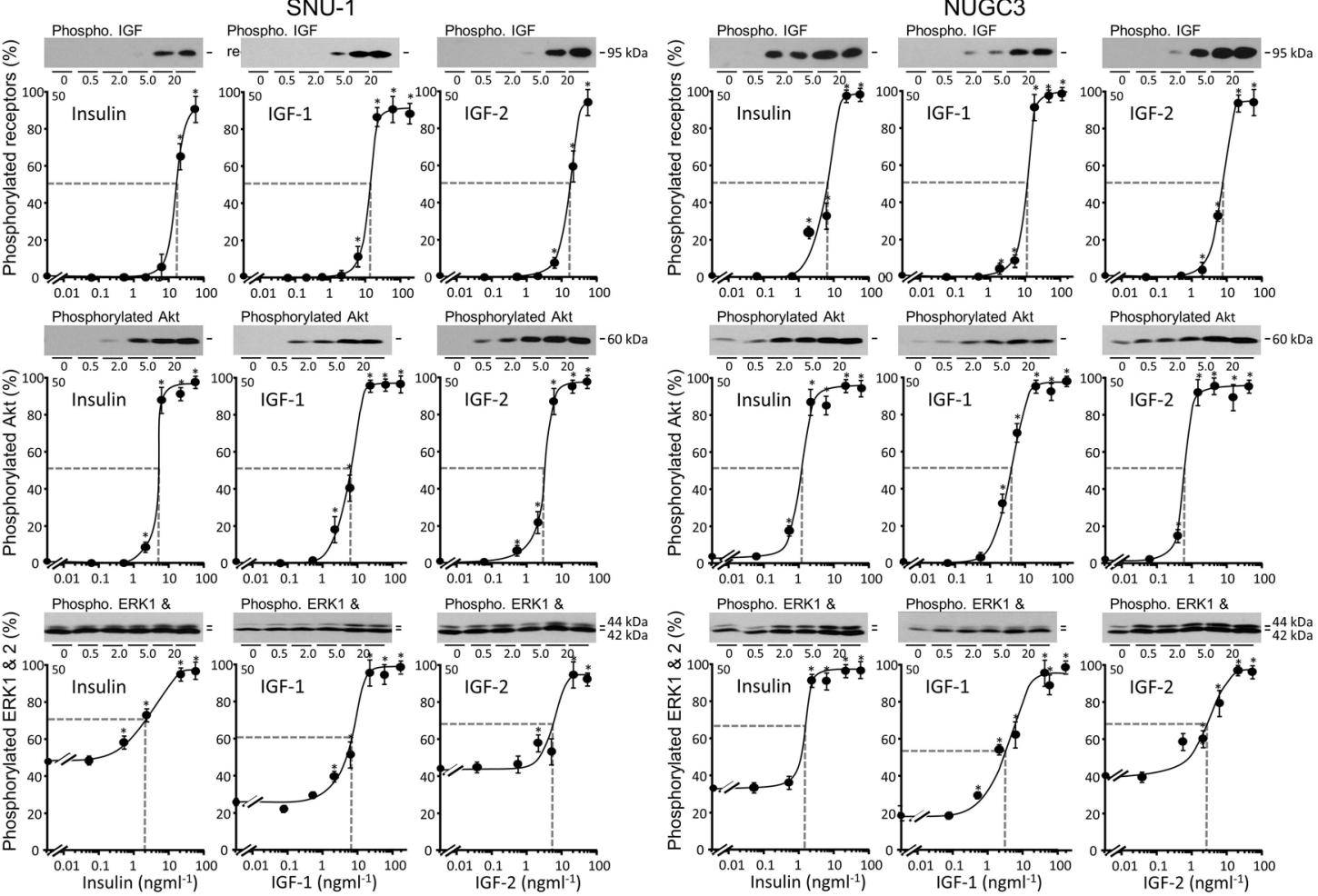

$\begin{array}{llllll}0.01 & 0.1 & 1 & 10 & 100 \\ \text { Phosphorylated Akt } & \end{array}$
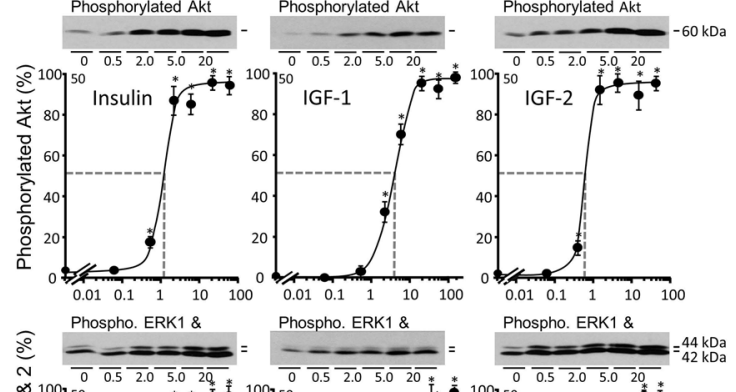

Phospho. ERK1 \&

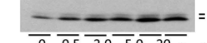

Phospho. ERK1 \&
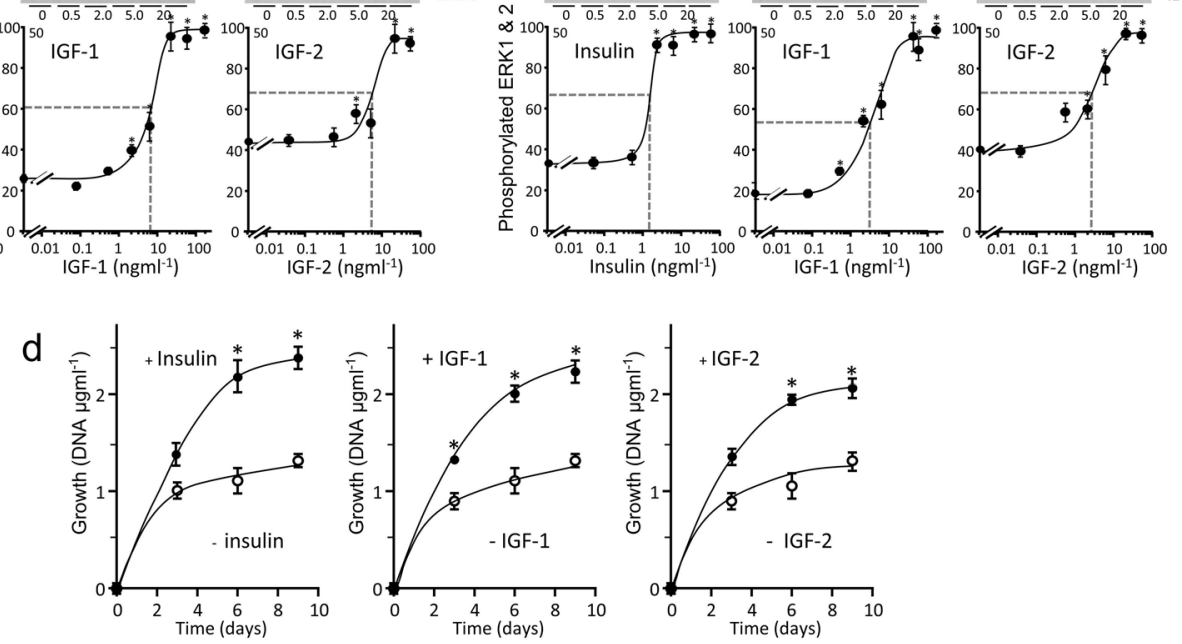
4Fig. 3 Expression of the genes that encode, and activity of, the three IGF ligands in human gastric adenocarcinomas. a Expression of the genes that encode insulin (INS), IGF-1 (IGF1) and IGF-2 (IGF2) in gastric adenocarcinomas presented as $\log _{2}$ transformed relative mRNA abundance [51] is shown against copy-number alterations as described in the legend to Fig. 1. The horizontal, brick red dotted lines indicate relative mRNA abundances of 20,000 (14.29 $\left.\log _{2}\right)$. Expression of INS and IGF1 is not, but of $I G F 2$ is weakly, associated with CNV (Kruskal Wallis; $p<0.05$ ). Copy number and relative high expression of $I N S, I G F 1$ and IGF2 were analysed in gastric adenocarcinomas as described in the legend to Fig. 1. b Expression of INS in normal (N) and tumour (Tu.) tissue of bladder carcinoma (Bl C.), breast carcinoma ( $\mathrm{Br}$ C.), cervical squamous cell carcinoma (Ce Sq), cholangiocarcinoma (Chol.), colon adenocarcinoma (C. Ad), oesophageal carcinoma (Oe. C.), glioblastoma (GBM), head and neck squamous cell carcinoma $(\mathrm{H} \& \mathrm{~N})$, kidney chromophobe (Ki Ch), kidney clear cell carcinoma ( $\mathrm{Ki} \mathrm{cC}$ ), kidney papillary cell carcinoma (Ki pC), hepatocellular carcinoma (HCC), lung adenocarcinoma ( $\mathrm{Lu}$ C.), lung squamous cell carcinoma (Lu Sq), pancreatic adenocarcinoma (P. Ad), prostate adenocarcinoma (Pr Ad), pheochromocytoma and paraganglioma $(\mathrm{Ph} \& \mathrm{P})$, rectal adenocarcinoma (R. Ad), sarcoma (Sar.), melanoma (Mel.) thyroid carcinoma (Th C.), thymoma (Thym.), gastric adenocarcinoma (G. Ad) and endometrial carcinoma (En C.) expressed as transcripts per million (tpm) [29]. c SNU-1 and NUGC3 were withdrawn from growth factor stimulation by culture in growth factor-depleted calf serum as described in the Methods. Withdrawn cells were cultured in serum-free medium for two hours and then in serum-free medium in the presence of the indicated concentrations of insulin, IGF-1 or IGF-2 and lysed. Phosphorylated (Phospho.) insulin Tyr 1150/1151 and type I IGF Tyr 1135/1136 receptors (IGF receptors), Akt Ser 473, ERK1 Thr 202/204 and ERK2 Thr $185 / 187$ were analysed by western transfer as described in the legend to Fig. 2. The relative $\mathrm{EC}_{50}$ values are indicated by blue lines. Asterisks indicate concentrations at which there was significantly more phosphorylated protein in the presence of ligand than in its absence (one-way ANOVA; $p<0.05$ ). d NUGC3 cells were withdrawn from stimulatory factors in serum by culture in withdrawal medium for one day, incubated in the absence or presence of $50 \mathrm{ngml}^{-1}$ insulin, IGF-1 or IGF-2 in withdrawal medium for the indicated lengths of time, lysed and DNA content measured. Asterisks indicate times at which there was significantly more DNA in the presence of ligand than in its absence (two-way ANOVA; insulin, $p<0.0001$; IGF-1, $p<0.0001$; IGF-2, $p<0.000)$

minority, of gastric adenocarcinomas (Fig. 3a). Median relative $I G F 1$ mRNA abundance was around $8\left(\log _{2}\right)$. Median relative $I G F 2$ mRNA abundance was higher. INS, IGF 1 and $I G F 2 \mathrm{CNV}$ and relative overexpression were detected in $13 \%$ of gastric tumours. Co-incident INS and IGF2 amplification occurs because INS lies $10 \mathrm{~kb}$ upstream of $I G F 2$ at $\mathrm{Chr}$ $11 \mathrm{p} 15.5$. Expression of $I G F 2$ was, but of $I N S$ and $I G F 1$ was not, associated with CNV (Kruskal Wallis; $p<0.05$ ). INS, $I G F 1$ and IGF2 mRNAs were measured in a separate cohort of 1065 gastric adenocarcinomas by microarray hybridisation [28]. Low or absent expression of INS, higher expression of IGF-1 and even higher expression of IGF2 were confirmed.

The rarity of INS expression in gastric adenocarcinoma led us to investigate its expression in other adult cancers, twenty three with comparator normal tissue (Fig. 3b) and nine without (data not shown) [29]. INS expression was detected in pancreatic adenocarcinoma and rare neural tumours, pheochromocytoma and paraganglioma, and in their and glioblastoma and thymoma's corresponding normal samples. Expression was highest in normal pancreas. Thus, apart from pancreatic adenocarcinoma, pheochromocytoma and paraganglioma, any direct tumour effects in other cancer types will depend upon pancreatic or pharmaceutical insulins.

\section{Responsiveness of gastric adenocarcinoma cells to insulin}

The concentrations at which insulin activated intracellular signal transduction in serum-free medium were compared to those of IGF-1 and IGF-2. Insulin stimulated concentration-dependant autophosphorylation of the IGF receptors, phosphorylation of Akt in the PI3-kinase/Akt pathway, and increased phosphorylation of ERK1 and ERK2 in the Ras/ Raf/MAPK pathway, (one-way ANOVA; $p<0.01$ ) (Fig. 3c). The relative $\mathrm{EC}_{50}$ values for insulin-stimulated protein phosphorylation in gastric adenocarcinoma cells, $1.2-5 \mathrm{ngml}^{-1}$ (0.2-2.6 nM) were similar to those of IGF-1 and IGF-2.

Proliferative effects of insulin on gastric adenocarcinoma cells were compared to those of IGF-1 and IGF-2. Over the first two days, growth rates in the absence and presence of ligand were not dissimilar due probably to the presence of residual serum-derived growth factors. Thereafter, cells grew more in the presence of insulin, IGF-1 or IGF-2 than in their absence. Growth was fivefold higher between days three and six in cells grown in the presence of insulin (twoway ANOVA; $p<0.0001$ ) (Fig. 3d). Cells did not reach confluence during these experiments.

To investigate effects of insulin on cell survival, caspasedependent apoptosis was induced with the kinase inhibitor staurosporine and cleaved PARP visualised in apoptotic nuclei by immunofluorescence (Fig. 4a). Cleaved PARP was detected in a smaller proportion of nuclei after incubation in the presence of insulin, indicative of protection against cell death. Similar levels of protection were effected by IGF-1 and IGF-2.

Metastatic gastric adenocarcinoma cells were protected by ligand against anoikis, which is programmed cell death induced by loss of cell attachment, in serum-free medium (Fig. 4b). This ligand-dependent protection was prevented by BMS-754807 in serum-free medium (two-way ANOVA; $p<0.001)$. Inhibition and activation of the PI3-kinase/Akt pathway, which is required for protection of gastric cancer cells from cell death [7], accompanied ligand-dependent protection against cell death and its prevention. Liganddependent protection of SNU-1 and NUGC3 from anoikis in serum-free medium, and from apoptosis, was inhibited also by BMS-754807 (data not shown). 


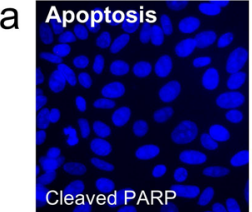

- staurosporine

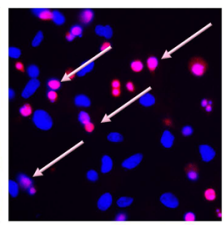

+ staurosporine

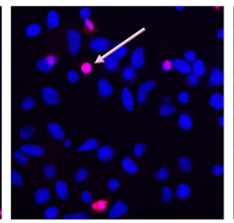

staurosporine + insulin

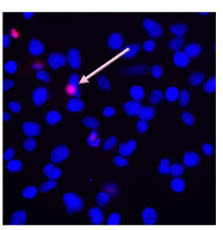

+ staurosporine + IGF-1

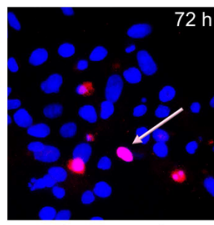

+ staurosporine + IGF-2

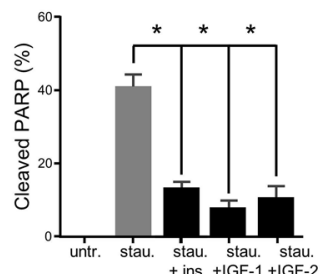

SNU-1

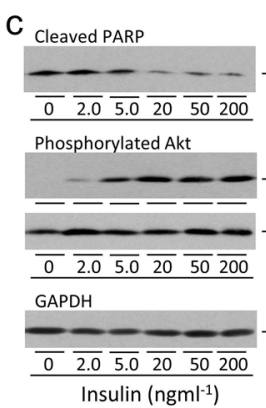
Cleaved PARP

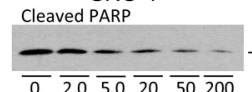

$\overline{0} \overline{2.0} \overline{5.0} \overline{20} \overline{50} \overline{200}$ Phosphorylated Akt

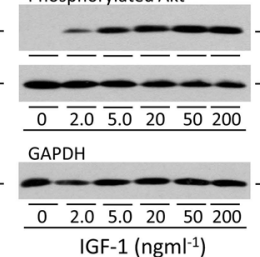

Cleaved PARP

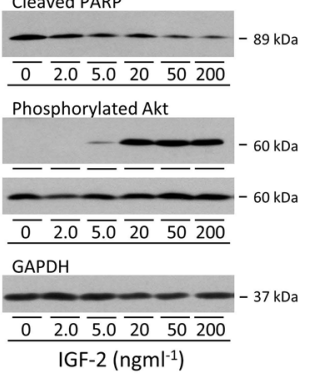

NUGC3
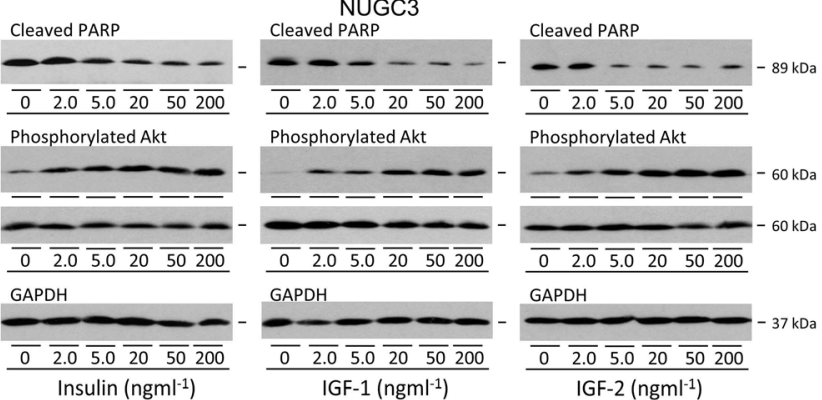

d Insulin receptor isoform B FnIII-2'

$710 \quad 717 \quad 718$

$\begin{array}{cc}729 & 730 \\ \text { PrgeValPro ArgLysThrSerSerGlyThrGlyAlaGluAspPro ArgProSer ArgLysArgArg Ser }\end{array}$
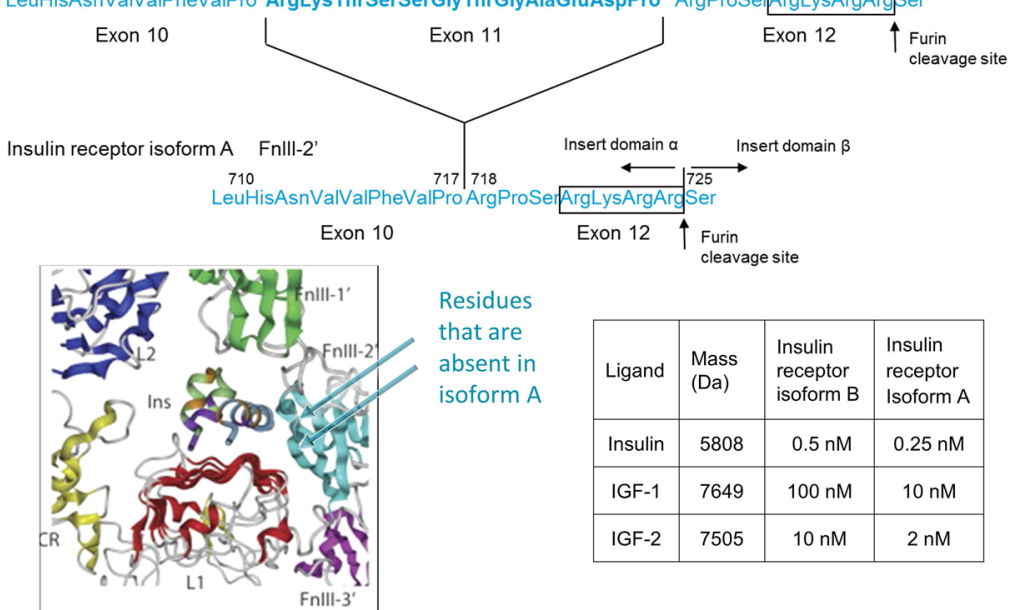

esidues

\begin{tabular}{|c|c|c|c|}
\hline Ligand & $\begin{array}{l}\text { Mass } \\
(\mathrm{Da})\end{array}$ & $\begin{array}{l}\text { Insulin } \\
\text { receptor } \\
\text { isoform B }\end{array}$ & $\begin{array}{l}\text { Insulin } \\
\text { receptor } \\
\text { Isoform A }\end{array}$ \\
\hline Insulin & 5808 & $0.5 \mathrm{nM}$ & $0.25 \mathrm{nM}$ \\
\hline IGF-1 & 7649 & $100 \mathrm{nM}$ & $10 \mathrm{nM}$ \\
\hline IGF-2 & 7505 & $10 \mathrm{nM}$ & $2 \mathrm{nM}$ \\
\hline
\end{tabular}

e

Insulin receptor isoform B
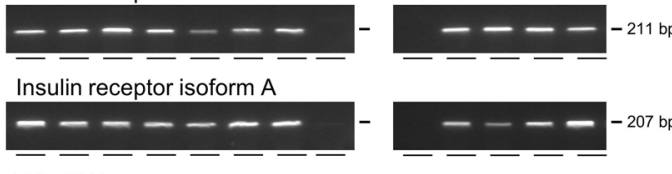

18S rRNA
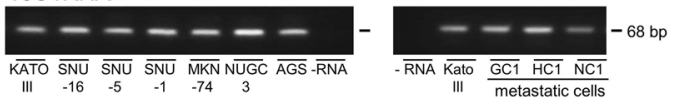

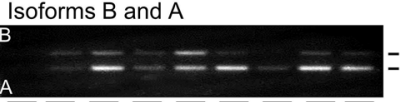

18S rRNA

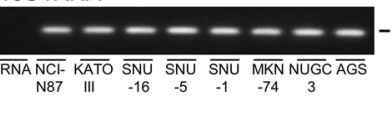

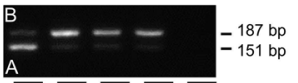

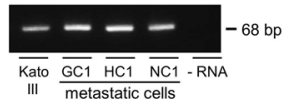


४Fig. 4 Cell survival effects of insulin, IGF-1 and IGF-2 in gastric adenocarcinoma. a NUGC3 were incubated in the absence or presence of $0.5 \mu \mathrm{M}$ staurosporine without or with $50 \mathrm{ngml}^{-1}$ ligand for $4 \mathrm{~h}$, fixed and evidence of cell death analysed by immunofluorescent detection of cleaved Asp 214 PARP (pink arrows). The proportions of cells in which cell death had been induced are shown as means \pm SEM (two-way ANOVA; $p<0.001$ ). b Metastatic cells isolated from patients were added to poly-HEMA-coated wells in serumfree medium to prevent attachment and induce anoikis and incubated in serum-free medium in the absence or presence of ligand (lig.) minus or plus BMS-754807 for $24 \mathrm{~h}$ after which cleaved PARP, phosphorylated Akt Ser 473, Akt and GAPDH were measured by western transfer. Asterisks indicate if there was statistically significantly less cleaved PARP or more phosphorylated Ser 473 Akt after incubation in the presence of ligand, or more cleaved PARP or less phosphorylated Ser $473 \mathrm{Akt}$ after incubation in the presence of ligand and BMS754807 , than in the presence of ligand alone (two-way ANOVA; $p<0.01$ ). NS indicates data are not significantly different. c SNU-1 and NUGC3 were incubated with staurosporine and different concentrations of ligand prior to analysis of cleaved PARP, phosphorylated Akt Ser 473, Akt and GAPDH by western transfer. $\mathbf{d}$ The primary sequences of the insulin receptor in the second fibronectin type III domain (FnIII-2') that differentiate isoform B from isoform A are shown (adapted from [10]). Insulin is shown positioned in the binding pocket of isoform B with the amino acid residues in FnIII-2'encoded by exon 11 that are absent in isoform A arrowed (adapted from [19]). The molecular masses of the IGF ligands and their affinities for insulin receptor isoforms B and A are listed [10]. Please see electronic supplementary material for further details (online resource 1). e RNA extracted from gastric cancer cells and metastatic patient samples incubated in untreated FCS-containing medium was reverse transcribed and cDNA amplified with primers designed to detect insulin receptor isoform B (211 bp), insulin receptor isoform A (207 bp), isoform B and isoform A simultaneously (187 bp and $151 \mathrm{bp}$, respectively) or $18 \mathrm{~S}$ rRNA (68 bp)

Incubation of gastric adenocarcinoma cells with different insulin, IGF-1 or IGF-2 concentrations prior to induction of apoptosis demonstrated concentration-dependent protection (Fig. 4c). Less cleaved PARP was detected at $5 \mathrm{ngml}^{-1}$ insulin, IGF-1 and IGF-2 and above. Activation of the PI3kinase/Akt pathway was detectable at $2 \mathrm{ngml}^{-1}$ ligand and above.

The concentrations at which insulin, IGF-1 and IGF-2 activated signal transduction and stimulated cell proliferation and survival indicated that activity might be via their cognate receptors. However, insulin receptor isoform A lacks twelve amino acids encoded by exon 11 [20] that occupy space in the insulin receptor ligand binding pocket of isoform B (Fig. 4d) [10, 30]. More capacious in their absence, isoform A's ligand binding pocket accommodates better, and has a higher affinity for, the larger IGF-1 and IGF-2 molecules [10, 19]. Please see online resource 1 for details of affinities for hybrid receptors.

Amplification of insulin receptor transcripts by RT-PCR detected both isoform $\mathrm{B}$ and isoform A mRNAs in all gastric adenocarcinoma cell lines and metastatic cells (Fig. 4e). Expression of isoform A means that IGF-1 and IGF-2 will activate the insulin receptor at lower concentrations than if only isoform B was expressed. Simultaneous amplification of both isoform mRNAs indicated that isoform A was relatively more abundant in some gastric adenocarcinoma cells, whereas isoform B was relatively more abundant in metastatic cells isolated from patients (Fig. 4e).

\section{Insulin receptor knockdown reduces growth and induces cell death}

The individual activities of the insulin and type I IGF receptors were tested by genetic knockdown. First, effective knockdown of insulin receptor was demonstrated (Fig. 5a). Insulin receptor knockdown reduced untreated FCS-stimulated growth of gastric adenocarcinoma cells (Fig. 5b). Similar effects of type I IGF receptor knockdown replicated previous results [7]. Images above the growth curves illustrate that receptor knockdown was maintained throughout the experiments.

The effects of receptor knockdown on cell cycle progression were tested. Analysis of BrdU incorporation into newly synthesised DNA demonstrated that $30 \%$ of cells cultured in untreated FCS-containing medium were in S-phase (Fig. 5c). Knockdown of the insulin receptor and type I IGF receptor [7] reduced the proportion of cells in S-phase two- to fourfold after two and three days, respectively. Similarly, the proportion of mitotic cells was reduced after knockdown of either receptor (One-way ANOVA; $p<0.0001$ ).

Fragmented nuclei of apoptotic cells discernible after transfection with siINSR2 (Fig. 5c) were clearly visible in higher magnification images (Fig. 6a). Thirty per cent of cells appeared apoptotic after $72 \mathrm{~h}$. Apoptotic nuclei were absent in cells transfected with scrambled siRNA and rare after transfection with siIGF1R2. That apoptosis was initiated by insulin receptor but not by type I IGF receptor knockdown was confirmed by detection of cleaved PARP specifically in nuclei of cells transfected with siINSR2 (Oneway ANOVA; $p<0.0001)$.

The cell survival activity of the insulin receptor was corroborated by transfection of SNU-1, MKN-74 and NUGC3 with siINSR2. PARP cleavage was induced after $48 \mathrm{~h}$ and persisted up to $96 \mathrm{~h}$ after transfection (Fig. 6b). Similar results were obtained with siINSR3 (Fig. 6c). In contrast, knockdown of the type I IGF receptor by transfection of SNU-1, MKN-74, NUGC3 or AGS with siIGF1R2 did not induce PARP cleavage (Fig. 6d). Equally, apoptosis was not induced by type I IGF receptor abrogation in metastatic cells isolated from patients.

The effects of simultaneous knockdown of the receptors was investigated. Transfection with siIGF1R2 reduced type I IGF receptor but not insulin receptor levels (Fig. 6e). Transfection with siINSR2 reduced specifically insulin receptor levels. More programmed cell death was induced by insulin receptor knockdown than by type I IGF receptor knockdown. 
a

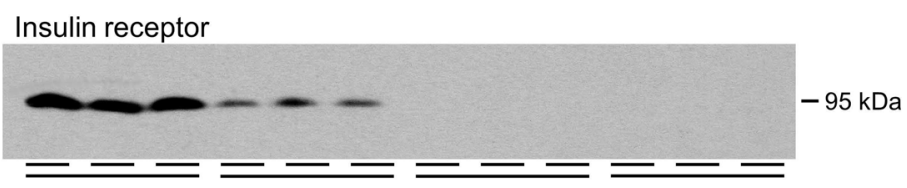

GAPDH

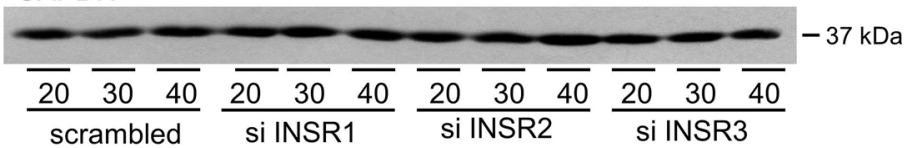

b
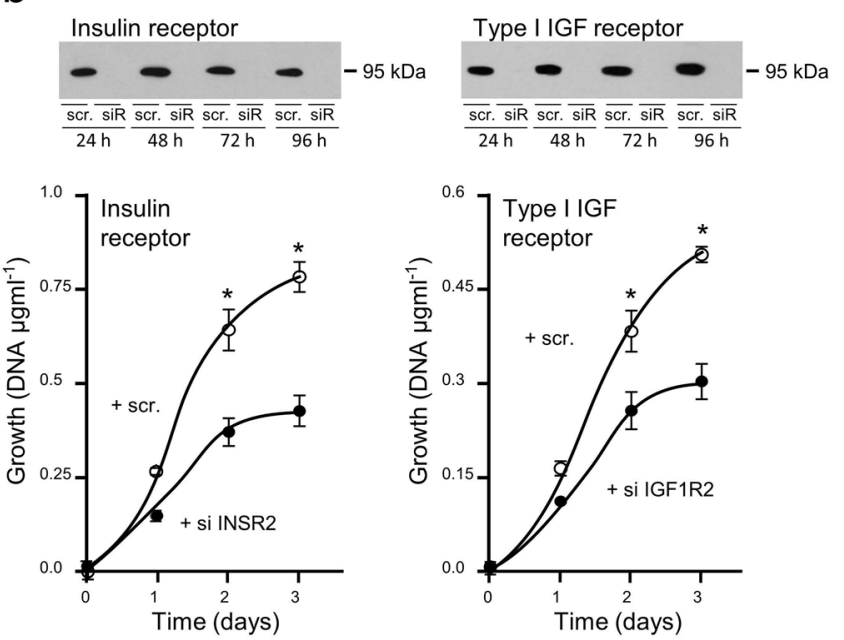

Fig. 5 Knockdown of the insulin receptor reduces gastric cancer cell growth and division. a NUGC3 cells were transfected with scrambled oligonucleotide, siINSR1, siINSR2 or siINSR3, cultured for three days in full, untreated FCS-containing medium after which insulin receptor levels were analysed by western transfer. b NUGC3 cells were transfected with scrambled oligonucleotide (scr.), siINSR2 (siR) or silGF1R2 (siR) and cultured in full, untreated FCS-containing medium for the indicated lengths of time prior to analysis of receptor expression or DNA content. Asterisks indicate times at which there was significantly less DNA after transfection with siINSR2 or
C
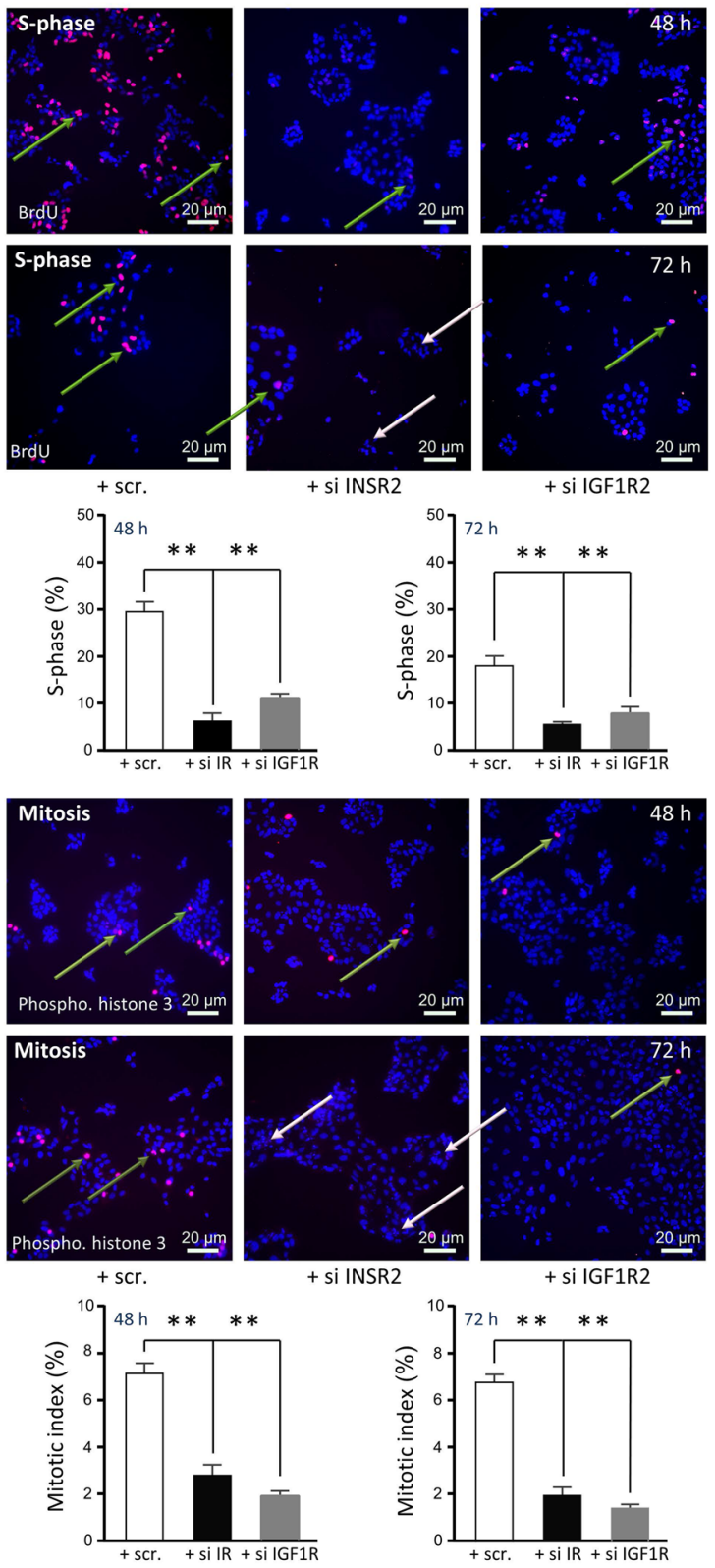

siIGF1R2 than with scrambled oligonucleotide (two-way ANOVA; $p<0.0001)$. c NUGC3 cells were transfected with scrambled oligonucleotide (scr.), siINSR2 (si IR) or siIGF1R2 (si IGF1R), plated onto coverslips, cultured in full, untreated FCS-containing medium for three days and assayed for BrdU incorporation (green arrows) or histone H3 Ser 10 phosphorylation (khaki arrows). Asterisks indicate if the proportion of cells in either phase of the cell cycle is significantly lower after transfection with siINSR2 or siIGF1R2 than with the scrambled oligonucleotide (one-way ANOVA; $p<0.0001$ ). Pale pink arrows indicate apoptotic cells 
Combined knockdown was no more effective than knockdown of the insulin receptor alone.

\section{Discussion}

Our finding that higher tumour INSR expression is associated with shorter overall patient survival concurs with a report that membranous insulin receptor is associated with shorter tumour-specific survival [31]. A trend towards an association between endothelial cell insulin receptor and survival was noted; single-cell transcriptome analysis could elucidate this observation. That patients whose tumour cells have higher INSR expression, and a priori higher insulin receptor levels, have worse survival implies that insulin promotes gastric cancer. Higher tumour cell insulin receptor concentration and availability should allow cells to achieve higher receptor occupancy and hence increased responsivity to insulin.

The association between higher IGFIR expression and shorter overall patient survival agrees with a previous study [32]. Higher $I G F 1 R$ expression is associated also with shorter overall survival in paediatric but not adult glioma [33].

Pharmacological inhibition was effective in gastric adenocarcinoma cells without amplification of ERBB2, FGFR2 or MET. Cell growth and mitosis were inhibited, and programmed cell death was initiated in the presence of the plethora of growth and survival factors that are present in untreated FCS. These findings are consistent with the insulin and IGF pathway having a significant role in triple-negative gastric adenocarcinoma cell proliferation and survival.

The present study focused on the $70 \%$ of gastric adenocarcinomas without amplification of ERBB2, FGFR2 or $M E T$. Those with amplification and overexpression are predicted to be driven predominantly by signal via the tyrosine kinase receptor encoded by the amplified oncogene. Nevertheless, NCI-N87, Kato III, SNU-16 and SNU-5 respond to IGF stimulation [7] and BMS-754807 reduced NCI-N87 growth (Fig. 1g). Insulin and IGF signal transduction in these cells, which have high insulin receptor levels, may be able to sustain growth and survival if the dominant receptor tyrosine kinase is targeted. Sensitivity to inhibition, and activity, of the insulin and IGF signal transduction pathway has been demonstrated in lapatinib- and trastuzumabresistant NCI-N87 [34, 35]. Further, insulin and type I IGF receptors mediated lapatinib resistance of HER2-amplified SNU-216 gastric cancer cells [34].

Calle et al. [9] concluded that increased levels of endogenous hormones associated with obesity, such as insulin, have a more profound effect on cancer death rates than they do on incidence. This is the first report of direct effects of insulin on gastric adenocarcinoma cells. Insulin activated signal transduction, stimulated cell growth and increased cell survival. INS was not expressed in most gastric adenocarcinomas, or in the majority of other adult cancers types. It can be inferred that direct cancer-promoting effects of insulin on tumour cells depend upon endocrine or therapeutic sources.

The relative $\mathrm{EC}_{50}$ insulin concentrations in gastric adenocarcinoma cells were $1.2-15 \mathrm{ng} / \mathrm{ml}(0.2-2.6 \mathrm{nM})$. These concentrations are above the relatively low fasted plasma insulin concentrations of leaner individuals $(0.1-0.52 \mathrm{ng} /$ $\mathrm{ml}(18-90 \mathrm{pM})$ [36]. But they overlap both the slightly higher fasted plasma insulin concentrations, and non-fasted concentrations, in the general population, $0.01-4.5 \mathrm{ng} / \mathrm{ml}$ (1.8-767.4 pM) and 0.09-8.7 $\mathrm{ng} / \mathrm{ml}(15.9-1365.9 \mathrm{pM})$, respectively [13].

Insulin-resistant individuals with compensatory hyperinsulinemia have high plasma insulin concentrations, $0.6-25 \mathrm{ng} / \mathrm{ml}(0.1-4.3 \mathrm{nM})$ [36, 37]. In patients with type II diabetes, therapeutic insulin concentrations reach $30 \mathrm{ng} / \mathrm{ml}$ $(5.2 \mathrm{nM})$ [38]. Thus some individuals in the general population, those with weight gain or hyperinsulinemia, and those who inject insulin, have plasma insulin concentrations at or above the $\mathrm{EC}_{50}$ insulin concentrations effective in gastric adenocarcinoma cells. Our findings could explain why overweight and obese individuals, and type I and type II diabetics, are more likely to present with symptomatic gastric cancer [12, 17, 39], and why obese men have twice the death rate from gastric cancer as lean individuals [9].

High tumour IGFI and IGF2 expression, IGF2 is the 25th most over-expressed gene in gastric adenocarcinoma [29], implies local IGF-1 and IGF-2 synthesis. Tumour synthesis coupled with demonstration that IGF-1 and IGF-2 stimulate gastric adenocarcinoma cell growth and survival [7, 40], suggests potential autocrine activity. Autocrine activities have been reported for IGF-1 [41, 42] and IGF-2 [40, $41,43]$. Twenty-five gastric adenocarcinomas had relative IGF-2 mRNA abundances $\geq 20,000\left(14.29 \log _{2}\right)$ of which only three had concurrent gene amplification. In the other cases, another mechanism such as loss of IGF2 imprinting, [44] or enhancer hijacking by tandem duplication [45] must account for the overexpression.

Genetic knockdown demonstrated that both receptors transmit mitogenic signals in gastric adenocarcinoma. This is the first report of a cytostatic effect of INSR knockdown. The cytostatic effect of $I G F I R$ knockdown agrees with previous findings in gastric, breast and pancreatic cancer [7, 23, 46].

Demonstration that the insulin receptor transmits a strong cell survival stimulus in gastric adenocarcinoma was unexpected. In a transgenic model of pancreatic neuroendocrine carcinogenesis and an oestrogen-unresponsive breast cancer cell line, insulin receptor knockdown had no effect alone but sensitised cells to pharmacological inhibition of the type I IGF receptor [47]. 
a
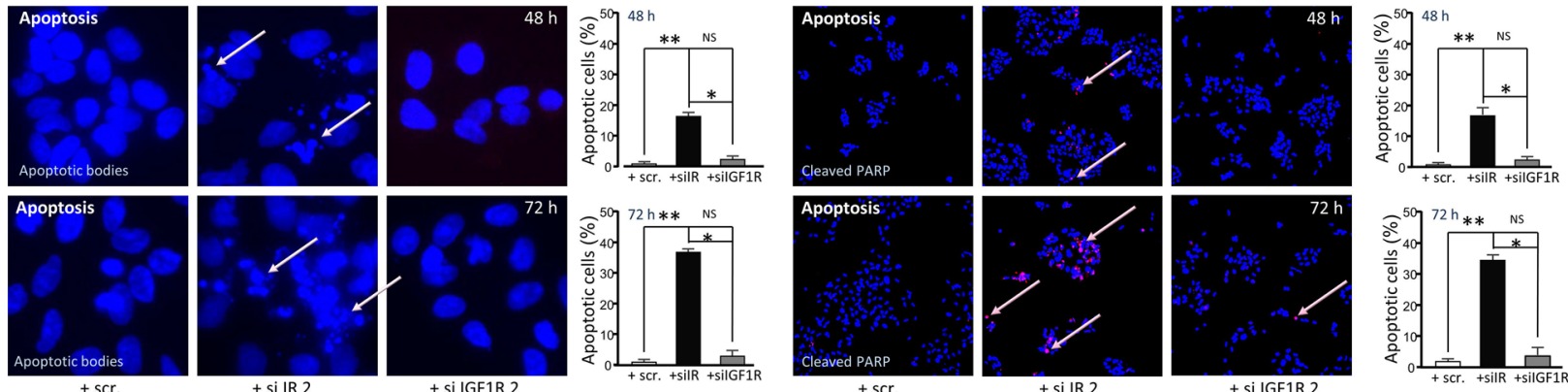

b
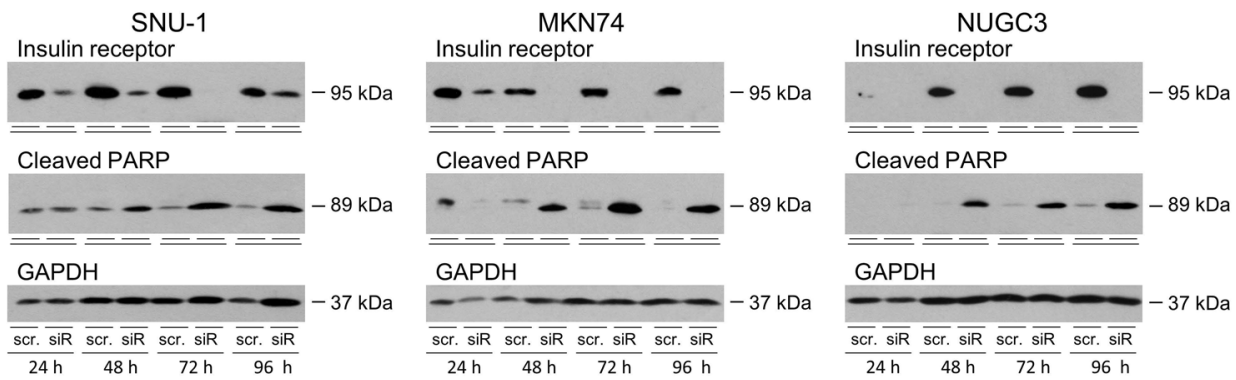

C

SNU-1

Insulin receptor
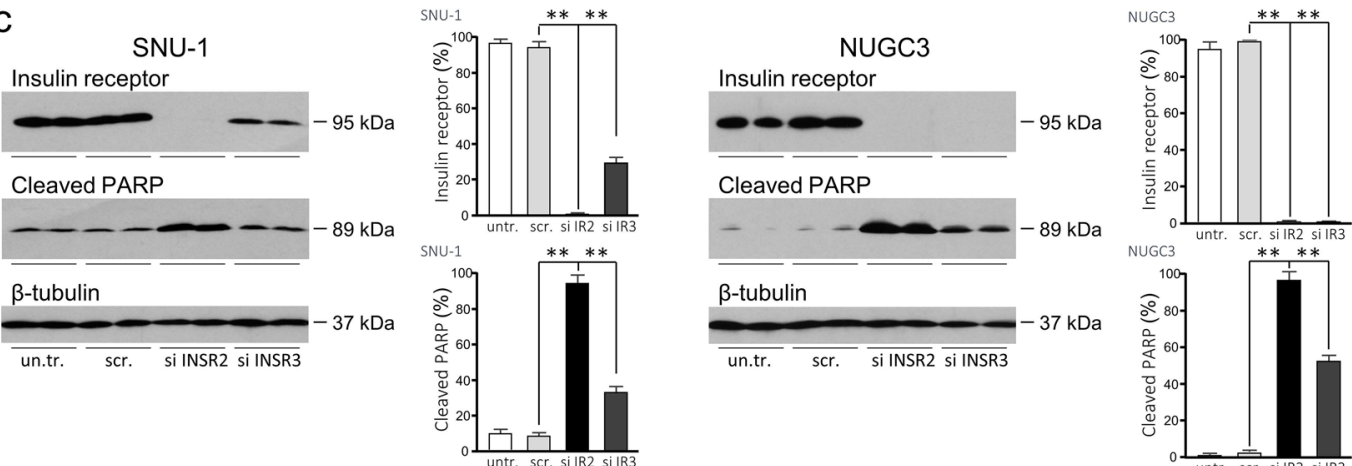

$\beta$-tubulin
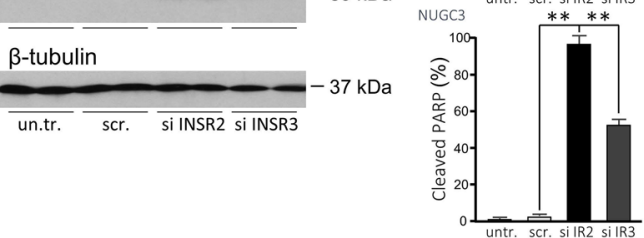

d

\section{Type I IGF receptor}

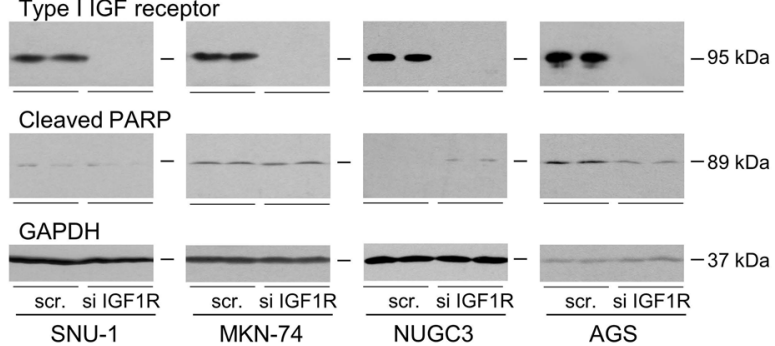

Type I IGF receptor

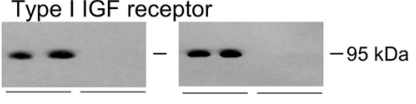

Cleaved PARP

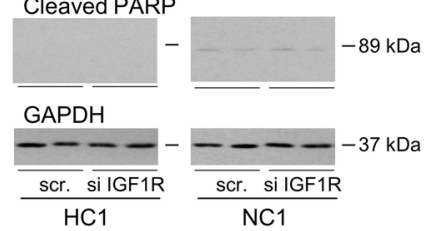

e

\section{Type I IGF receptor}

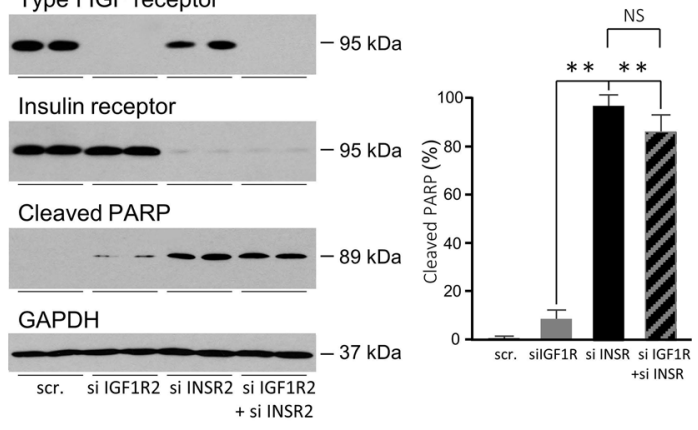


4Fig. 6 Knockdown of the insulin receptor induces cell death in gastric cancer cells. a NUGC3 were transfected with scrambled oligonucleotide (scr.), siINSR2 or siIGF1R2 and analysed as described in the legend to Fig. 5. High magnification images facilitate visualisation of apoptotic nuclei (pale pink arrows). Cells were analysed next for the presence of cleaved PARP (pink arrows). Asterisks indicate that the proportion of apoptotic cells, or cells with cleaved PARP, is significantly higher after transfection with siINSR2 than with the scrambled oligonucleotide $(* *)$ or siIGF1R2 (*) (one-way ANOVA; $p<0.0001$ ). NS indicates data are not significantly different. b SNU-1, MKN-74 and NUGC3 cells were transfected with scrambled oligonucleotide (scr.) or siINSR2 (siR) and cultured as indicated in untreated-FCScontaining medium prior to analysis of insulin receptor, cleaved PARP or GAPDH by western transfer. c SNU-1 and NUGC3 were transfected with scrambled oligonucleotide, siINSR2 or siINSR3 and cultured for three days in untreated-FCS-containing medium prior to measurement of insulin receptor, cleaved PARP or $\beta$-tubulin by western transfer. Asterisks (**) indicate that there was significantly less insulin receptor or more cleaved PARP after transfection with siINSR 2 or siINSR3 than with scrambled oligonucleotide (one-way ANOVA; $p<0.001)$. d SNU-1, MKN-74, NUGC3 and AGS, and patient samples, $\mathrm{HC} 1$ and $\mathrm{NC1}$, were transfected with scrambled oligonucleotide (scr.) or silGF1R2, cultured for three days in untreatedFCS-containing medium and type I IGF receptor, cleaved PARP and GAPDH analysed. e NUGC3 were transfected with scrambled oligonucleotide (scr.), siINSR2, siIGF1R2 or both siINSR2 and siIGF1R2 and cultured in untreated-FCS-containing medium for three days prior to measurement of type I IGF receptor, insulin receptor, cleaved PARP or GAPDH by western transfer. There was significantly more cleaved PARP after transfection with siINSR2, or siINSR2 and siIGF1R2 (one-way ANOVA; $p<0.001$ )

Dependence of gastric adenocarcinoma cell survival upon insulin receptor but not type I IGF receptor indicates that IGF-1 and IGF-2 promote cell survival through the insulin receptor. Expression of insulin receptor isoform A, for which IGF-1 and IGF-2 have higher affinities than they have for isoform B, [10, 30] by gastric adenocarcinoma cells makes this supposition plausible. Relatively higher expression of insulin receptor isoform $\mathrm{B}$, for which insulin has considerably higher affinity than IGF-1 or IGF-2 has, was apparent in metastatic gastric adenocarcinoma cells. A corollary is that preferential responsiveness to insulin is predicted in these metastatic cells.

Our findings support the importance of interventions to lower plasma insulin levels in diabetics with cancer, and to reduce weight and consequent hyperinsulinemia, in overweight and obese cancer patients. Future work should investigate the dual roles of insulin and its receptor in other cancer types associated with obesity, diabetes mellitus or high insulin states $[9,10,48]$.

Supplementary Information The online version contains supplementary material available at https://doi.org/10.1007/s10120-021-01236-y.

Acknowledgements We thank Jon Shenfine, Stephanie Needham, Ruth Plummer and Brendan Luey for their contributions and support especially in the early stages of our study, and the upper gastrointestinal surgical team especially Joshua M Brown. We are grateful to
Bristol-Myers Squibb for the gift of BMS-754807. This work was supported by the Northern Oesophago Gastric Cancer Fund, the JGW Patterson Foundation, the Newcastle-upon-Tyne Hospitals NHS Charity and Cancer Research UK (Grant number: C27826/A11524).

Author contribution MS acquired and analyzed the data and drafted the manuscript, SMG obtained funding, provided supervision and reviewed the manuscript, and FEBM was responsible for study concept and design, obtaining funding, supervision, data analysis and preparation of the manuscript.

\section{Declarations}

Conflict of interest The authors declare that they have no conflict of interest.

Open Access This article is licensed under a Creative Commons Attribution 4.0 International License, which permits use, sharing, adaptation, distribution and reproduction in any medium or format, as long as you give appropriate credit to the original author(s) and the source, provide a link to the Creative Commons licence, and indicate if changes were made. The images or other third party material in this article are included in the article's Creative Commons licence, unless indicated otherwise in a credit line to the material. If material is not included in the article's Creative Commons licence and your intended use is not permitted by statutory regulation or exceeds the permitted use, you will need to obtain permission directly from the copyright holder. To view a copy of this licence, visit http://creativecommons.org/licenses/by/4.0/.

\section{References}

1. Bray F, Ferlay J, Soerjomataram I, Siegel RL, Torre LA, Jemal A. Global cancer statistics 2018: GLOBOCAN estimates of incidence and mortality worldwide for 36 cancers in 185 countries. CA Cancer J Clin. 2018;68(6):394-424.

2. Mongan AM, Kalachand R, King S, O'Farrell NJ, Power D, Ravi N, et al. Outcomes in gastric and junctional cancer using neoadjuvant and adjuvant chemotherapy (epirubicin, oxaliplatin, and capecitabine) and radical surgery. Ir J Med Sci. 2015;184(2):417-23.

3. Dulak AM, Schumacher SE, van Lieshout J, Imamura Y, Fox C, Shim B, et al. Gastrointestinal adenocarcinomas of the esophagus, stomach, and colon exhibit distinct patterns of genome instability and oncogenesis. Cancer Res. 2012;72(17):4383-93. https://doi. org/10.1158/0008-5472.CAN-11-3893

4. van Grieken NCT, Aoyma T, Chambers PA, Bottomley D, Ward LC, Inam I, et al. KRAS and BRAF mutations are rare and related to DNA mismatch repair deficiency in gastric cancer from the East and the West: Results from a large international multicentre study. Br J Cancer. 2013;108(7):1495-501.

5. Bang YJ, Van Cutsem E, Feyereislova A, Chung HC, Shen L, Sawaki A, et al. Trastuzumab in combination with chemotherapy versus chemotherapy alone for treatment of HER2-positive advanced gastric or gastro-oesophageal junction cancer (ToGA): a phase 3, open-label, randomised controlled trial. Lancet. 2010;376(9742):687-97.

6. Apicella M, Corso S, Giordano S. Targeted therapies for gastric cancer: failures and hopes from clinical trials. Oncotarget. 2017;8(34):57654-69.

7. Saisana M, Griffin SM, May FEB. Importance of the type I insulin-like growth factor receptor in HER2, FGFR2 and 
MET-unamplified gastric cancer with and without Ras pathway activation. Oncotarget. 2016;7(34):54445-62.

8. Yang P, Zhou Y, Chen B, Wan HW, Jia GQ, Bai HL, et al. Overweight, obesity and gastric cancer risk: Results from a meta-analysis of cohort studies. Eur J Cancer. 2009;45(16):2867-73.

9. Calle EE, Rodriguez C, Walker-Thurmond K, Thun MJ. Overweight, obesity, and mortality from cancer in a prospectively studied cohort of US adults. N Engl J Med. 2003;348(17):1625-38.

10. Westley RL, May FEB. A twenty-first century cancer epidemic caused by obesity: the involvement of insulin, diabetes, and insulin-like growth factors. Int J Endocrinol. 2013. https://doi.org/10. $1155 / 2013 / 632461$

11. Shlomai G, Neel B, LeRoith D, Gallagher EJ. Type 2 diabetes mellitus and cancer: the role of pharmacotherapy. J Clin Oncol. 2016;34(35):4261-9. https://doi.org/10.1200/JCO.2016.67.4044

12. Tseng $\mathrm{CH}$, Tseng FH. Diabetes and gastric cancer: the potential links. World J Gastroenterol. 2014;20(7):1701-11.

13. Hidaka A, Sasazuki S, Goto A, Sawada N, Shimazu T, Yamaji T, et al. Plasma insulin, C-peptide and blood glucose and the risk of gastric cancer: The Japan Public Health Center-based prospective study. Int J Cancer. 2015;136(6):1402-10.

14. Gelin L, Li JW, Corbin KL, Jahan I, Nunemaker CS. Metformin inhibits mouse islet insulin secretion and alters intracellular calcium in a concentration-dependent and duration-dependent manner near the circulating range. J Diabetes Res. 2018. https://doi. org/10.1155/2018/9163052.

15. Kim YI, Kim SY, Cho SJ, Park JH, Choi IJ, Lee YJ, et al. Longterm metformin use reduces gastric cancer risk in type 2 diabetics without insulin treatment: a nationwide cohort study. Aliment Pharmacol Ther. 2014;39(8):854-63.

16. Kim J, Hyun HJ, Choi EA, Kim Y, Bae YJ, Kang HT. Metformin use reduced the risk of stomach cancer in diabetic patients in Korea: an analysis of Korean NHIS-HEALS database. Gastric Cancer. 2020;23(6):1075-83.

17. Zendehdel K, Nyren O, Ostenson CG, Adami HO, Ekbom A, Ye WM. Cancer incidence in patients with type 1 diabetes mellitus: A population-based cohort study in Sweden. J Natl Cancer Inst. 2003;95(23):1797-800.

18. Carstensen B, Read SH, Friis S, Sund R, Keskimaki I, Svensson $\mathrm{AM}$, et al. Cancer incidence in persons with type 1 diabetes: a five-country study of 9,000 cancers in type 1 diabetic individuals. Diabetologia. 2016;59(5):980-8.

19. Lawrence MC, McKern NM, Ward CW. Insulin receptor structure and its implications for the IGF-1 receptor. Curr Opin Struct Biol. 2007;17(6):699-705.

20. Ullrich A, Bell JR, Chen EY, Herrera R, Petruzzelli LM, Dull TJ, et al. Human insulin-receptor and its relationship to the tyrosine kinase family of oncogenes. Nature. 1985;313(6005):756-61.

21. Frasca F, Pandini C, Scalia P, Sciacca L, Mineo R, Costantino A, et al. Insulin receptor isoform A, a newly recognized, high-affinity insulin-like growth factor II receptor in fetal and cancer cells. Mol Cell Biol. 1999;19(5):3278-88.

22. May FEB, Westley BR. Cloning of estrogen-regulated messenger-rna sequences from human-breast cancer-cells. Cancer Res. 1986;46(12):6034-40.

23. Davison Z, de Blacquiere GE, Westley BR, May FEB. Insulinlike growth factor-dependent proliferation and survival of triplenegative breast cancer cells: implications for therapy. Neoplasia. 2011;13(6):504-15.

24. Luey BC, May FEB. Insulin-like growth factors are essential to prevent anoikis in oestrogen-responsive breast cancer cells: importance of the type I IGF receptor and PI3-kinase/Akt pathway. Mol Cancer. 2016;15(8):1-15.

25. Goto H, Tomono Y, Ajiro K, Kosako H, Fujita M, Sakurai M, et al. Identification of a novel phosphorylation site on histone $\mathrm{H} 3$ coupled with mitotic chromosome condensation. J Biol Chem. 1999;274(36):25543-9.

26. Donaghue C, Westley BR, May FEB. Selective promoter usage of the human estrogen receptor-alpha gene and its regulation by estrogen. Mol Endocrinol. 1999;13(11):1934-50.

27. May FEB, Westley BR. TFF3 is a valuable predictive biomarker of endocrine response in metastatic breast cancer. Endocr Relat Cancer. 2015;22(3):465-79.

28. Szasz AM, Lanczky A, Nagy A, Forster S, Hark K, Green JE, et al. Cross-validation of survival associated biomarkers in gastric cancer using transcriptomic data of 1,065 patients. Oncotarget. 2016;7(31):49322-33.

29. Chandrashekar DS, Bashel B, Balasubramanya SAH, Creighton CJ, Ponce-Rodriguez I, Chakravarthi B, et al. UALCAN: a portal for facilitating tumor subgroup gene expression and survival analyses. Neoplasia. 2017;19(8):649-58.

30. Ward CW, Lawrence MC, Streltsov VA, Adams TE, McKern NM. The insulin and EGF receptor structures: new insights into ligand-induced receptor activation. Trends Biochem Sci. 2007;32(3):129-37.

31. Heckl SM, Wiesener V, Behrens HM, Ulase D, Kruger S, Rocken C. The expression of the insulin receptor in gastric cancer correlates with the HER2 status and may have putative therapeutic implications. Gastric Cancer. 2019;22(6):1130-42.

32. Matsubara J, Yamada Y, Hirashima Y, Takahari D, Okita NT, Kato K, et al. Impact of insulin-like growth factor type 1 receptor, epidermal growth factor receptor, and HER2 expressions on outcomes of patients with gastric cancer. Clin Cancer Res. 2008;14(10):3022-9.

33. Simpson AD, Soo YWJ, Rieunier G, Aleksic T, Ansorge O, Jones C, et al. Type 1 IGF receptor associates with adverse outcome and cellular radioresistance in paediatric high-grade glioma. Br J Cancer. 2020;122(5):624-9. https://doi.org/10.1038/ s41416-019-0677-1

34. Zhang Z, Wang JP, Ji DM, Wang CC, Liu RJ, Wu Z, et al. Functional genetic approach identifies MET, HER3, IGF1R, INSR pathways as determinants of lapatinib unresponsiveness in HER2positive gastric cancer. Clin Cancer Res. 2014;20(17):4559-73.

35. Zuo Q, Liu J, Zhang J, Wu M, Guo L, Liao W. Development of trastuzumab-resistant human gastric carcinoma cell lines and mechanisms of drug resistance. Sci Rep. 2015;5:11634.

36. Wilcox G. Insulin and insulin resistance. Clin Biochem Rev. 2005;26(2):19-39.

37. Weyer C, Funahashi T, Tanaka S, Hotta K, Matsuzawa Y, Pratley $\mathrm{RE}$, et al. Hypoadiponectinemia in obesity and type 2 diabetes: Close association with insulin resistance and hyperinsulinemia. J Clin Endocrinol Metab. 2001;86(5):1930-5.

38. Mayfield JA, White RD. Insulin therapy for type 2 diabetes: Rescue, augmentation, and replacement of beta-cell function (vol 70, pg 489, 2004). Am Fam Physician. 2004;70(11):2079-80.

39. Chen Y, Liu LX, Wang XL, Wang JH, Yan ZP, Cheng JM, et al. Body mass index and risk of gastric cancer: a meta-analysis of a population with more than ten million from 24 prospective studies. Cancer Epidemiol Biomark Prev. 2013;22(8):1395-408.

40. Pavelic K, Kolak T, Kapitanovic S, Radosevic S, Spaventi S, Kruslin B, et al. Gastric cancer: the role of insulin-like growth factor 2 (IGF 2) and its receptors (IGF I R and M6-P/IGF 2R). J Pathol. 2003;201(3):430-8.

41. Breuhahn K, Longerich T, Schirmacher P. Dysregulation of growth factor signaling in human hepatocellular carcinoma. Oncogene. 2006;25(27):3787-800.

42. Nakanishi Y, Mulshine JL, Kasprzyk PG, Natale RB, Maneckjee $\mathrm{R}$, Avis I, et al. Insulin-like growth factor-I can mediate autocrine proliferation of human small cell lung-cancer cell-lines invitro. J Clin Investig. 1988;82(1):354-9. 
43. Rikhof B, van der Graaf WTA, Suurmeijer AJH, van Doorn J, Meersma GJ, Groenen PJTA, et al. 'Big'-insulin-like growth factor-II signaling is an autocrine survival pathway in gastrointestinal stromal tumors. Am J Pathol. 2012;181(1):303-12.

44. Wu MS, Wang HP, Lin CC, Sheu JC, Shun CT, Lee WJ, et al. Loss of imprinting and overexpression of IGF2 gene in gastric adenocarcinoma. Cancer Lett. 1997;120(1):9-14.

45. Weischenfeldt J, Dubash T, Drainas AP, Mardin BR, Chen YY, Stutz AM, et al. Pan-cancer analysis of somatic copy-number alterations implicates IRS4 and IGF2 in enhancer hijacking. Nat Genet. 2017;49(1):65-74.

46. Subramani R, Lopez-Valdez R, Arumugam A, Nandy S, Boopalan $\mathrm{T}$, Lakshmanaswamy R. Targeting insulin-like growth factor 1 receptor inhibits pancreatic cancer growth and metastasis. Plos One. 2014;9(5):e97016.

47. Ulanet DB, Ludwig DL, Kahn CR, Hanahan D. Insulin receptor functionally enhances multistage tumor progression and conveys intrinsic resistance to IGF-1R targeted therapy. Proc Natl Acad Sci USA. 2010;107(24):10791-8.
48. Giovannucci E, Harlan DM, Archer MC, Bergenstal RM, Gapstur SM, Habel LA, et al. Diabetes and cancer a consensus report. Diabetes Care. 2010;33(7):1674-85.

49. Cerami E, Gao JJ, Dogrusoz U, Gross BE, Sumer SO, Aksoy $\mathrm{BA}$, et al. The $\mathrm{cBio}$ cancer genomics portal: an open platform for exploring multidimensional cancer genomics data. Cancer Discov. 2012;2(5):401-4.

50. Gao JJ, Aksoy BA, Dogrusoz U, Dresdner G, Gross B, Sumer SO, et al. Integrative analysis of complex cancer genomics and clinical profiles using the cBioPortal. Science Signaling. 2013;6(269):pl1. https://doi.org/10.1126/scisignal.2004088

51. Li B, Dewey CN. RSEM: accurate transcript quantification from RNA-Seq data with or without a reference genome. BMC Bioinformatics. 2011;12:323.

Publisher's Note Springer Nature remains neutral with regard to jurisdictional claims in published maps and institutional affiliations. 